\title{
Recent climatic, cryospheric, and hydrological changes over the interior of western Canada: a review and synthesis
}

\author{
Chris M. DeBeer ${ }^{1}$, Howard S. Wheater ${ }^{1}$, Sean K. Carey ${ }^{2}$, and Kwok P. Chun ${ }^{1, \mathrm{a}}$ \\ ${ }^{1}$ Global Institute for Water Security, University of Saskatchewan, Saskatoon, Saskatchewan, Canada \\ ${ }^{2}$ School of Geography and Earth Sciences, McMaster University, Hamilton, Ontario, Canada \\ ${ }^{a}$ now at: Department of Geography, Hong Kong Baptist University, Kowloon Tong, Hong Kong, China \\ Correspondence to: Chris M. DeBeer (chris.debeer@usask.ca)
}

Received: 13 August 2015 - Published in Hydrol. Earth Syst. Sci. Discuss.: 31 August 2015

Revised: 23 March 2016 - Accepted: 3 April 2016 - Published: 25 April 2016

\begin{abstract}
It is well established that the Earth's climate system has warmed significantly over the past several decades, and in association there have been widespread changes in various other Earth system components. This has been especially prevalent in the cold regions of the northern midto high latitudes. Examples of these changes can be found within the western and northern interior of Canada, a region that exemplifies the scientific and societal issues faced in many other similar parts of the world, and where impacts have global-scale consequences. This region has been the geographic focus of a large amount of previous research on changing climatic, cryospheric, and hydrological regimes in recent decades, while current initiatives such as the Changing Cold Regions Network (CCRN) introduced in this review seek to further develop the understanding and diagnosis of this change and hence improve the capacity to predict future change. This paper provides a comprehensive review of the observed changes in various Earth system components and a concise and up-to-date regional picture of some of the temporal trends over the interior of western Canada since the mid- or late 20th century. The focus is on air temperature, precipitation, seasonal snow cover, mountain glaciers, permafrost, freshwater ice cover, and river discharge. Important long-term observational networks and data sets are described, and qualitative linkages among the changing components are highlighted. Increases in air temperature are the most notable changes within the domain, rising on average $2{ }^{\circ} \mathrm{C}$ throughout the western interior since 1950 . This increase in air temperature is associated with hydrologically important changes to precipitation regimes and unambiguous declines in snow cover depth, persistence, and spatial ex-
\end{abstract}

tent. Consequences of warming air temperatures have caused mountain glaciers to recede at all latitudes, permafrost to thaw at its southern limit, and active layers over permafrost to thicken. Despite these changes, integrated effects on stream flow are complex and often offsetting. Following a review of the current literature, we provide insight from a network of northern research catchments and other sites detailing how climate change confounds hydrological responses at smaller scales, and we recommend several priority research areas that will be a focus of continued work in CCRN. Given the complex interactions and process responses to climate change, it is argued that further conceptual understanding and quantitative diagnosis of the mechanisms of change over a range of scales is required before projections of future change can be made with confidence.

\section{Introduction}

Recent warming of the Earth's climate system has been impacting many biogeophysical systems and their interactions globally (IPCC, 2013). Changes have been particularly great in the northern high latitudes, where observations show shifts in the amount and phase of precipitation, diminishing seasonal snow cover, retreat and loss of glaciers, warming and thawing of permafrost, earlier breakup of seasonal freshwater ice cover, changes in the timing and magnitude of river discharge, and altered composition, structure, and density of terrestrial vegetation communities (Serreze et al., 2000; ACIA, 2004; Hinzman et al., 2005; White et al., 2007; Prowse et al., 2009b; Callaghan et al., 2011a; Derksen et al., 2012; AMAP, 
2012; Bush et al., 2014). Responses to climatic and other environmental changes may be incremental or alternately characterized by threshold-type behaviour, often involving complex feedbacks, and there is increased sensitivity to warming in areas with winter temperatures near freezing associated with the phase change of water at $0^{\circ} \mathrm{C}$ (e.g., Adam et al., 2009). Understanding past changes in these systems is important yet difficult in part because of these complexities. Adding to the uncertainty, observational data sets are generally limited to a relatively short period of record on the order of decades and there is limited understanding of longer-term climate and environmental variability. Evaluating change across data sets is challenging as data may not be homogeneous; it typically reflects different spatial and temporal scales (e.g., in situ versus a satellite-derived average), and may be responding to different processes depending on how and where measurements are collected. Anthropogenic factors such as land and water management may also have a considerable impact (Nazemi and Wheater, 2014) and confound interpretation of Earth system change.

The interior of western Canada provides an immediate example of cold region environmental changes observed globally and the societal issues faced in the context of such changes. Changes, including those listed above, have been pervasive, while the costs associated with recent hydroclimatic extreme events (e.g., floods, drought, and wildfire) have been increasing (e.g., Hanesiak et al., 2011; Pomeroy et al., 2015). The principal continental-scale drainages, the Mackenzie and Saskatchewan River systems, support a major area of Canada's food and energy production, mining, forestry, critical riverine and delta ecosystems, growing cities, rural and aboriginal communities, and freshwater supply to the Arctic Ocean and Hudson Bay. The region is highly vulnerable to climate change with pressures from natural resource and hydroelectric development, irrigation demands, and population growth exacerbating the impacts (Martz et al., 2007; MRBB, 2012). Consequently, climate and environmental change here are of concern, not only at local and regional levels but also at the global scale as this impacts the global natural resource and food trades, and regional Earth system change influences the global climate system (RIFWP, 2013).

This area of Canada is the geographic focus of a major research initiative, the Changing Cold Regions Network (CCRN; DeBeer et al., 2015; www.ccrnetwork.ca), which aims to improve the understanding, diagnosis, and prediction of interactions among the cryospheric, ecological, hydrological, and climatic components of the changing Earth system at multiple spatial scales over the Mackenzie and Saskatchewan River basins (Fig. 1). The CCRN project was recently adopted as a Regional Hydro-Climate Project (RHP) by the Global Water and Energy Exchanges (GEWEX) Hydro-Climate Panel. An early objective of CCRN is to characterize observed Earth system changes across the interior of western Canada over the past several decades, including an

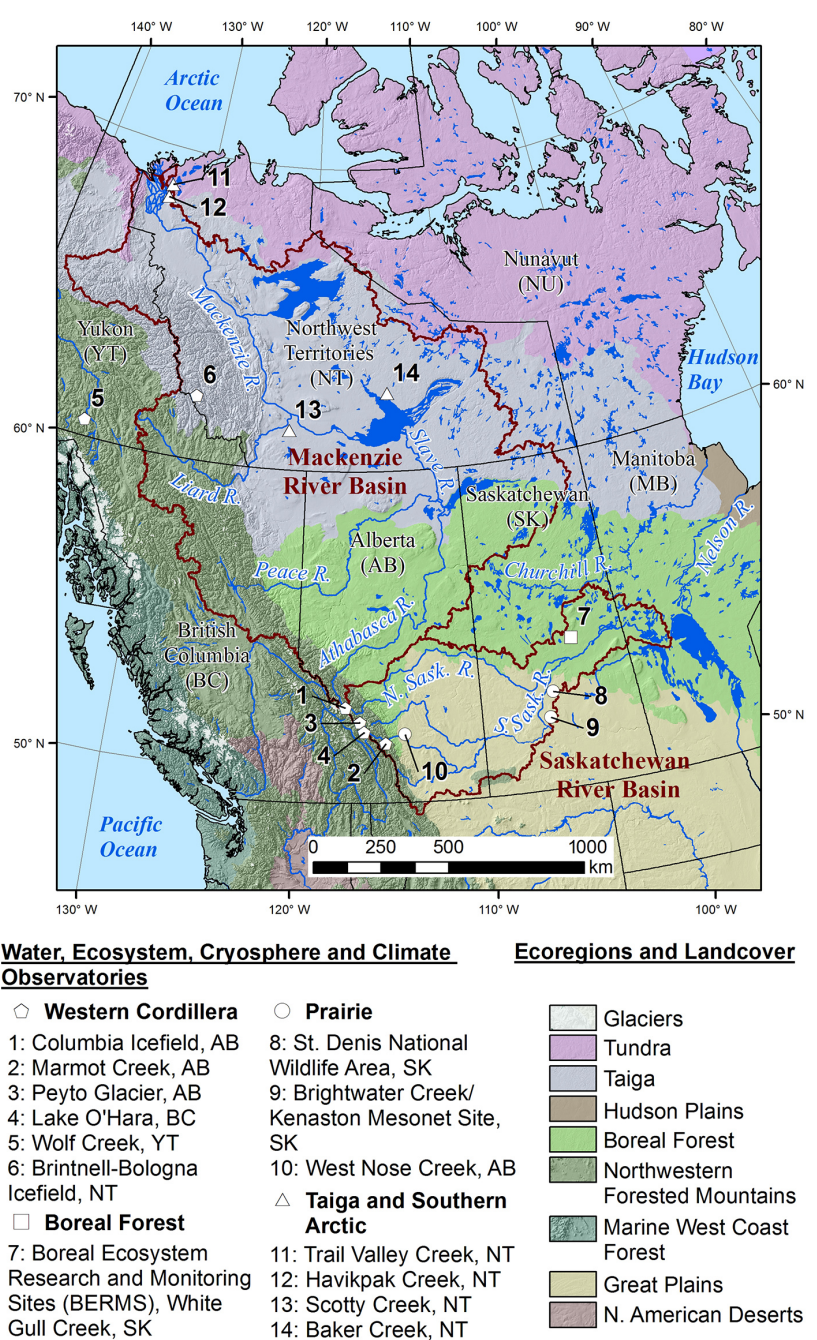

Figure 1. Map of the CCRN geographic study domain in the interior of western and northern Canada, showing the major river systems, ecoregions, and land cover, as well as the location of the WECC observatories. Source data are from the North American Environmental Atlas (http://www.cec.org/sites/default/atlas/map/) and the National Hydro Network (http://www.geobase.ca); the projection is UTM Zone 11 on the North American Datum of 1983.

inventory and statistical analyses of change as observed from long-term federal and provincial observational networks and other regional data sets. A network of local Water, Ecosystem, Climate, and Cryosphere (WECC) observatories that span different environments within the domain provides finer details and process-level insights into the observed changes (Fig. 1). Subsequent scientific objectives of CCRN involve the development of improved diagnostic and predictive modelling tools and their application in better understanding this change and predicting interactions and feedbacks among the changing Earth system components from local to regional scales. 
There has been a substantial amount of previous work aimed at characterizing and quantifying recent trends and variability in the climate and other Earth system components over this region. The CCRN builds on a legacy of other preceding research initiatives, including the Mackenzie GEWEX Study (MAGS; Stewart et al., 1998; Woo et al., 2008; www.usask.ca/geography/MAGS), the Boreal Ecosystem-Atmosphere Study (BOREAS; Sellers et al., 1997; Hall, 1999), the Drought Research Initiative (DRI; Stewart et al., 2011; www.drinetwork.ca), the Western Canadian Cryospheric Network (WC2N; http://wc2n.unbc.ca), the International Polar Year (IPY), and the Improved Processes and Parameterization for Prediction in Cold Regions Hydrology Network (IP3; www.usask.ca/ip3), among others. These major studies provided important observations and insights into change, while also providing the foundation for further investigations. Current parallel initiatives to the CCRN include the Canadian Network for Regional Climate and Weather Processes (CNRCWP; www.cnrcwp.uqam.ca) and the Canadian Snow and Sea Ice Evolution Network (CanSISE; www.cansise.ca). Considering this work, the aim of this paper is to bring together and review the recent climatic, cryospheric, and hydrological changes over the interior of western Canada documented in the literature and to provide a concise and up-to-date regional picture of the recent trends. Furthermore, we use insights from the WECC observatories to provide synthesis and guidance for future research questions linking climate change to hydrological responses.

In the following sections we describe changes and trends in surface air temperature, precipitation, seasonal snow cover, mountain glaciers and ice fields, permafrost, freshwater ice cover, and river discharge. The focus is generally on regional assessments of change based on extensive observing networks, which provide context for more detailed local observations of change at CCRN WECC observatories and elsewhere. Some principal observation networks and other important sources of regional or long-term data for the detection of change are briefly described. We consider the issue of distinguishing long-term trends from short-term variability or periodicity in records of limited length, together with the role of large-scale, low-frequency oceanic-atmospheric oscillations in driving changes over various timescales. The paper concludes with some remarks on the quality and length of observational data sets, a synopsis of the qualitative linkages among the observed changes in Earth system components, and a short discussion on the complexities of climatic and cryospheric process interactions and hydrological responses based on insights from local-scale observations and experimental studies at some of the WECC observatories. This provides the context for the diagnosis of change to be pursued as subsequent work in CCRN, including the development of improved conceptual understanding of process response and quantitative diagnostic modelling of these changes.

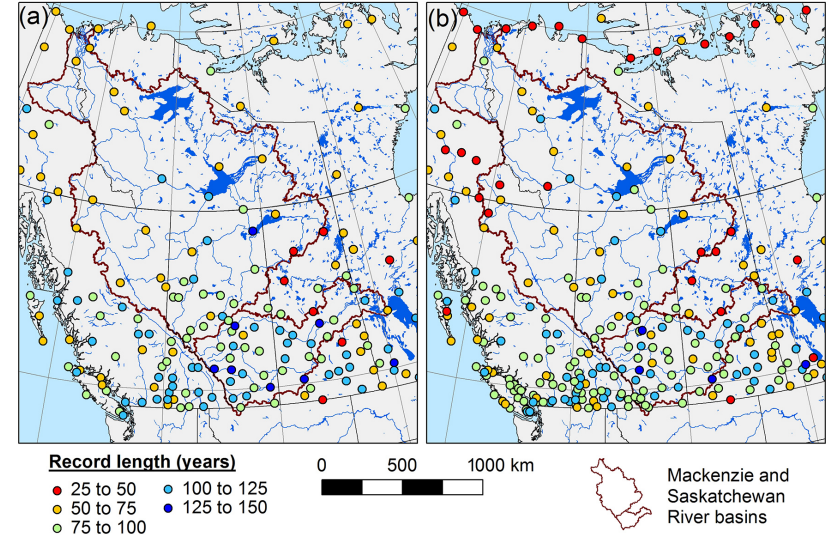

Figure 2. Map of station density and record length for (a) temperature and (b) precipitation measurements used in the AHCCD of Environment Canada (http://www.ec.gc.ca/dccha-ahccd/).

\section{Air temperature}

\subsection{Context}

Surface air temperature and its diurnal and seasonal variability is a fundamental climatic element characterizing a region and affects nearly all other hydro-meteorological conditions, including evaporation rate and precipitation phase and type. In cold regions, cryospheric and hydrological regimes are strongly influenced by air temperature and its variation, especially around $0{ }^{\circ} \mathrm{C}$ in association with the melting of snow and ice and the transition between snowfall and rain. Across the interior of western Canada, mean annual air temperature (for the period 1981-2010) varies considerably, ranging from 5 to $10^{\circ} \mathrm{C}$ in the southwest to -5 to $-10^{\circ} \mathrm{C}$ in the northern part of the region (Environment Canada, 2016). In summer, average temperatures range between 10 and $20^{\circ} \mathrm{C}$ from north to south across the region, while in winter these range from about -30 to $-5^{\circ} \mathrm{C}$. During the spring period, the seasonal mean $0{ }^{\circ} \mathrm{C}$ isotherm moves northward over a period of several months, beginning in March and early April in the south through until about late May and June in the north, influencing the timing of snow and ice melt and the spring freshet.

\subsection{Adjusted and homogenized temperature data set for Canada}

To facilitate research on climate and environmental change, the Climate Research Division of Environment Canada has developed an Adjusted and Homogenized Canadian Climate Dataset (AHCCD; www.ec.gc.ca/dccha-ahccd/). These data are based on federal monitoring stations across the country and incorporate several adjustments to the original station records to address shifts from changes in instrumentation and observing practices. Monthly adjustments were interpolated to each calendar day to produce daily maximum and minimum temperatures, and in some cases observations 
from multiple stations were joined to generate longer time series (Vincent et al., 2012). The current version contains records for 338 Canadian locations, but station density and record length decrease considerably toward the north, while the data availability over most of the Arctic and sub-Arctic parts of this region is restricted to the mid-1940s to present (Fig. 2a). Based on these data, annual, seasonal, and monthly temperature anomalies (departures from the 1961-1990 average) have been interpolated to a $50 \mathrm{~km}$ grid (CANGRD) by Environment Canada, covering southern Canada from 1900 and the entire country from 1948 (http://open.canada.ca/ data/en/dataset/3d4b68a5-13bc-48bb-ad10-801128aa6604). Rapić et al. (2015) provide more details on the CANGRD product.

\subsection{Changes in annual and seasonal air temperatures}

Recent analyses based on the AHCCD indicate that mean annual air temperature trends at stations across Canada have been dominated by statistically significant increases of about $1.5^{\circ} \mathrm{C}$ between 1950 and 2010 (Zhang et al., 2000, 2011; Vincent et al., 2012, 2015). There is a strong spatial coherence in the trends, with the strongest warming over western and northwestern Canada $\left(1.5-3^{\circ} \mathrm{C}\right)$. Nighttime warming (assessed from average daily minimum temperatures) has been slightly greater than daytime warming (from average daily maximum temperatures) (Zhang et al., 2000; Vincent et al., 2012). The analysis of Vincent et al. (2012) indicates that nationally the warmest year on record was 2010 (the last year of data used in that analysis), followed by 2006 and 1998 .

To illustrate the spatial pattern and magnitude of recent trends in surface air temperature over western Canada, we analyzed annual and seasonal CANGRD temperature data for the period 1950-2012. Trends were derived following Zhang et al. (2000), with a first-order autoregression process used to adjust the temporal autocorrelations within the climate series. A two-step approach was used to estimate the autocorrelation parameter $(\varphi)$ and trend slope $(\beta)$ iteratively and remove the autocorrelation from the time series. Iterations were continued until the difference in the $\varphi$ and $\beta$ estimates in two consecutive steps was less than $1 \%$; the value of $\beta$ was estimated from the de-autocorrelated time series based on the method of Sen (1968). The $P$ value of the trend slope from the de-autocorrelated series was computed using a rank trend test from Mann (1945) and Kendall (1975).

The results are shown in Fig. 3. Annual mean air temperature trends (Fig. 3a) show strong spatial coherence with slightly greater warming in the northern areas (as found in other studies), with statistical significance at the $95 \%$ confidence level at all grid points. On average, temperature over the region has increased by just over $2{ }^{\circ} \mathrm{C}$ in the 63 -year period, which exceeds the average increase over the global land surface of $1.2^{\circ} \mathrm{C}$ for the same period (based on the Global Historical Climate Network-Monthly (GHCN-M) data set available through the National Centers for Environmental In-
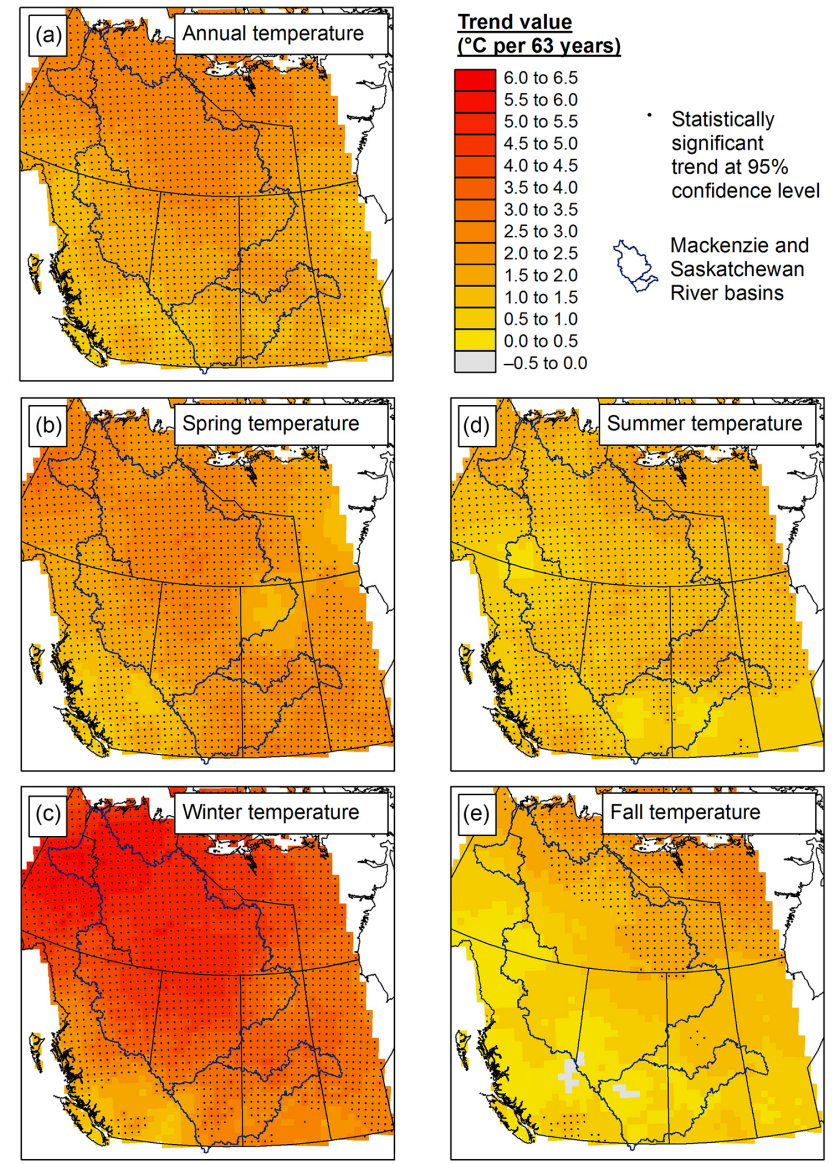

Figure 3. Spatial patterns of trends $\left({ }^{\circ} \mathrm{C}\right.$ per 63 years $)$ in annual and seasonal average air temperatures over the period 1950-2012 across western Canada, based on analysis of CANGRD temperature data.

formation; www.ncdc.noaa.gov/climate-monitoring/). Seasonally, the greatest warming has occurred during winter (Fig. 3c) and, to a lesser extent, spring (Fig. 3b), while warming in the summer (Fig. 3d) and fall (Fig. 3e) has been less pronounced with fewer statistically significant trends. In winter, the average temperature increase over the region was $3.9^{\circ} \mathrm{C}$, with a maximum increase of up to $6^{\circ} \mathrm{C}$ in parts of the northern Mackenzie basin and surrounding areas. Comparison with the global-scale analysis of Hansen et al. (2010) shows that winter warming here is among the highest of that worldwide. Consistent with this warming, Bonsal and Prowse (2003) observed significant trends toward earlier spring $0{ }^{\circ} \mathrm{C}$ isotherm dates over the region, ranging from 5 to as much as 20 days earlier over the latter half of the 20th century. From our analysis, temperature increases during spring, summer, and fall over western Canada averaged 2.2, 1.2, and $1.1^{\circ} \mathrm{C}$, respectively, all of which also exceed the corresponding global trends.

Large-scale modes of oceanic-atmospheric circulation influence surface air temperatures on various timescales over western Canada and thus factor in to the observed trends and 
interannual variability. These include, for example, El NiñoSouthern Oscillation (ENSO), the Pacific Decadal Oscillation (PDO), the North Atlantic Oscillation (NAO), and the Arctic Oscillation, among others. Bonsal et al. (2001b) found that ENSO and PDO influence winter temperature here, most strongly during El Niño episodes. At these times, positive PDO phases were associated with strong positive temperature anomalies, while negative PDO phases were associated with strong negative anomalies. They noted an increase in the occurrence of El Niño events and predominantly positive PDO winters after 1976, which would, in part, account for some of the observed winter warming. Vincent et al. (2015) quantified the component of seasonal and annual temperature trends associated with the NAO and PDO over Canada during 1948-2012. Their analysis confirmed that the PDO signal explained some of the observed trends in winter and spring, accounting for between a few tenths of a degree up to $2{ }^{\circ} \mathrm{C}$ of the warming in some areas. However, after removal of the influence of these indices, statistically significant trends were still observed. Bonsal and Prowse (2003) found that despite a link between $0{ }^{\circ} \mathrm{C}$ isotherm dates and various indices such as ENSO, PDO, NAO, and others, a relatively small amount of overall variance was explained. Although such large-scale patterns influence regional temperatures, the period since the mid-20th century is sufficiently long to capture the main (known) periodic effects, and these alone do not explain the long-term changes.

\subsection{Changes in daily and extreme air temperatures}

Not only have average annual and seasonal temperatures increased across the region, but major changes in extremes such as maximum, minimum, and other percentiles of monthly and daily temperature have been observed. Earlier work using the first generation AHCCD showed that over the latter half of the 20th century most stations exhibited increasing trends in the lower and higher percentiles of daily minimum and maximum temperature distributions, and there was a reduction in areas experiencing abnormal and extreme cold conditions with a concomitant increase in areas experiencing abnormal and extreme warm conditions (Zhang et al., 2000; Bonsal et al., 2001a). Bonsal et al. (2001a) noted this translates into fewer days with extreme low temperature (mainly during winter, spring, and summer) and more days with extreme high temperature (mostly winter and spring). They also reported a greater increase in the daily minimum temperatures (i.e., greater nighttime warming), thereby reducing intra-seasonal standard deviation of daily temperature. Vincent and Mekis (2006) examined a number of other indices, including frost days, cold days, cold nights, warm summer days, warm days, warm nights, diurnal temperature range, and standard deviation of minimum temperature (see their Table 1 for all definitions). They found widespread reductions in the number of cold days and nights (maximum/minimum temperatures $<10$ th percentile of the corre- sponding distributions) from 1950 to 2003 ranging from 10 to 50 days per year fewer over the period and, to a lesser extent, increases in the number of warm days, nights, and warm summer days. Other indices showed mostly mixed, non-significant trends. Mekis et al. (2015) examined trends in extreme heat and extreme cold events (days with at least one hourly humidex value above 30 and with at least one hourly wind chill value below -30, respectively) from 1953 to 2012 at 126 stations across Canada. They found that extreme heat events had increased significantly at many of the stations across Canada and extreme cold events had decreased significantly at virtually all stations. Wang et al. (2014) assessed changes in 1-in-20-year extreme temperatures (from annual maxima and minima of daily temperature series) from 1961 to 2010 and found that warming was greatest for the extreme low temperatures and was stronger in the northwestern part of Canada. Little warming was observed in the extreme high temperatures. They also reported that warming was stronger in winter than summer and stronger during nighttime than daytime, in accordance with Bonsal et al. (2001a).

Other studies have examined the variation in the intensity, duration, and frequency of cold and warm spells (defined as 3 or more consecutive days with minimum/maximum temperatures below/above the 20th/80th percentile of the corresponding distributions). Shabbar and Bonsal (2003) found that winter warm spells were increasing in frequency from 1950 to 1998 with up to three or four more events each year over the period and that these were becoming on average 1-4 days longer. Winter cold spells showed mixed trends in frequency, but a clear decrease in duration (1-4 days shorter) and intensity $\left(3-6^{\circ} \mathrm{C}\right.$ warmer). Analysis of summer warm spells by Mekis and Vincent (2008) from 1950 to 2007 showed a slight increase in frequency of about two events per year over the period. The influence of ENSO has been found to have a role in the frequency of cold and warm spells. For example, Shabbar and Bonsal (2004) reported that El Niño events were associated with significant increases in the occurrence of winter warm spells and the number of extreme warm days and decreases in the occurrence of winter cold spells and the number of extreme cold days, while the opposite was generally found for La Niña events.

\section{Precipitation}

\subsection{Context}

Like air temperature, precipitation is a fundamental climatic element characterizing a region that influences the cryospheric and hydrological regime. For instance, the amount, timing, intensity, duration, and phase of precipitation, along with other characteristics such as its seasonality and spatial and elevational distribution, control the formation and development of seasonal snowpacks (and their melt during instances of rain on snow), glacier accumulation, 
soil moisture and storage conditions in a watershed, and ultimately hydrological responses such as runoff. Annual and seasonal mean precipitation totals vary more strongly than temperature over western Canada, as influenced by latitude, elevation, distance from moisture sources, and other factors. Total amounts vary from up to a few hundred millimetres per year in the north and also parts of the interior plains of southwestern Canada, to many hundreds and up to thousands of millimetres per year in the Rocky Mountains (Environment Canada, 2016). Snowfall accounts for about $30 \%$ of total annual precipitation in the southern interior plains and up to more than $60 \%$ in the far north and in high-elevation areas of the Rocky Mountains (Woo et al., 2008).

\subsection{Adjusted precipitation data set for Canada}

As with surface air temperature, the Climate Research Division of Environment Canada has developed an adjusted precipitation data set for assessing changes and variability in Canadian precipitation (www.ec.gc.ca/dccha-ahccd/). Careful adjustments were made for known measurement issues in the station data for 464 locations across the country (Mekis and Vincent, 2011). Issues include wind undercatch, evaporation and wetting losses, snow water equivalent (SWE) estimation from depth measurement as influenced by variable snow densities, trace observations, and amounts accumulated over several days. It is noted that measurement of solid precipitation in particular is highly problematic and associated with large uncertainties in both raw data and corrected products. As with the temperature data, there is a low density of stations in the north and the data availability is mostly limited to the period since the mid-1940s here (Fig. 2b). Annual and monthly anomalies from the 1961-1990 baseline period were expressed as normalized percentage departures and interpolated to the $50 \mathrm{~km}$ resolution CANGRD by Environment Canada, covering southern Canada from 1900 and the entire country from 1948. Rapić et al. (2015) found that CANGRD produced trends that were up to twice the magnitude of a multi-data-set average in their evaluation of the consistency among various widely used gridded observationbased climate data sets over the Canadian Arctic. This is related to the adjustment of the station precipitation data for CANGRD and shows the importance of including corrections in gridded climate data sets.

\subsection{Changes in annual and seasonal precipitation}

In general, studies using the AHCCD have noted an increasing trend in the total annual precipitation over most parts of western Canada since about 1950 (Zhang et al., 2000, 2011; Mekis and Vincent, 2011; Vincent et al., 2015). To provide an up-to-date regional picture of the annual and seasonal trends, we analyzed the CANGRD precipitation data set over western Canada for the period 1950-2012 using the same methodology as described above for air temperature. Figures
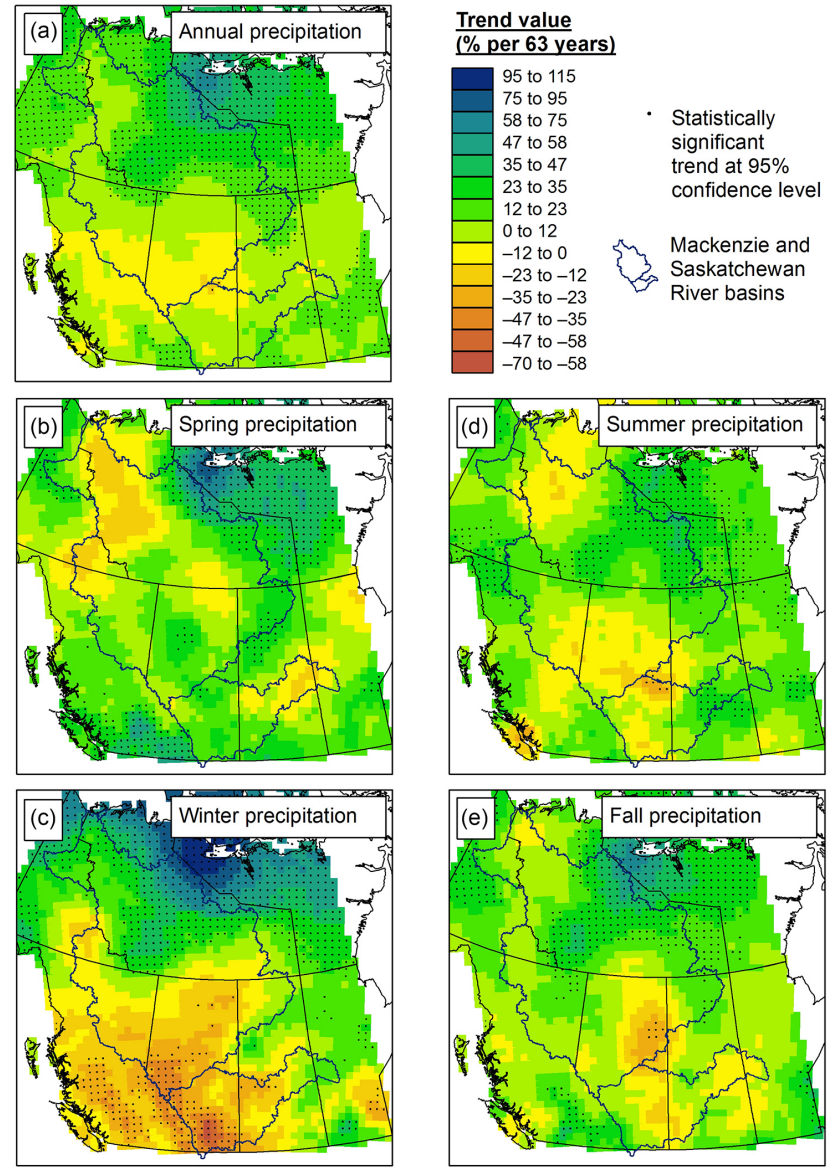

Figure 4. Spatial patterns of trends (percent per 63 years) in annual and seasonal totals of precipitation over the period 1950-2012 across western Canada, based on analysis of CANGRD precipitation data.

4 and 5 provide relative changes (as a percentage of the average) and absolute changes, respectively. On average, annual precipitation has increased by about $14 \%(50 \mathrm{~mm})$ over the region since 1950 (Figs. 4a and 5a); however, there is considerable variability in the magnitude and significance of local trends. Most of the increase has been in the north, where precipitation has risen locally by as much as $60 \%(\sim 200 \mathrm{~mm})$. Caution needs to be used in interpreting these trends, however, as some of the areas showing large increasing trends coincide with a very low density of surface observing stations (Fig. 2b). In most other parts of the Mackenzie and Saskatchewan River basins, the trends are not statistically significant and are low in magnitude with mixed sign.

The seasonal precipitation trends also exhibit large variability across the region (Figs. 4b-e, 5b-e). Broadly, the spatial patterns of trends in summer and fall, and to some extent spring, are similar. In winter, there is a clear divide between increasing trends in the north and decreasing trends in the south. In most of the northern Mackenzie basin, winter precipitation has increased by about $30-50 \%$, while in 

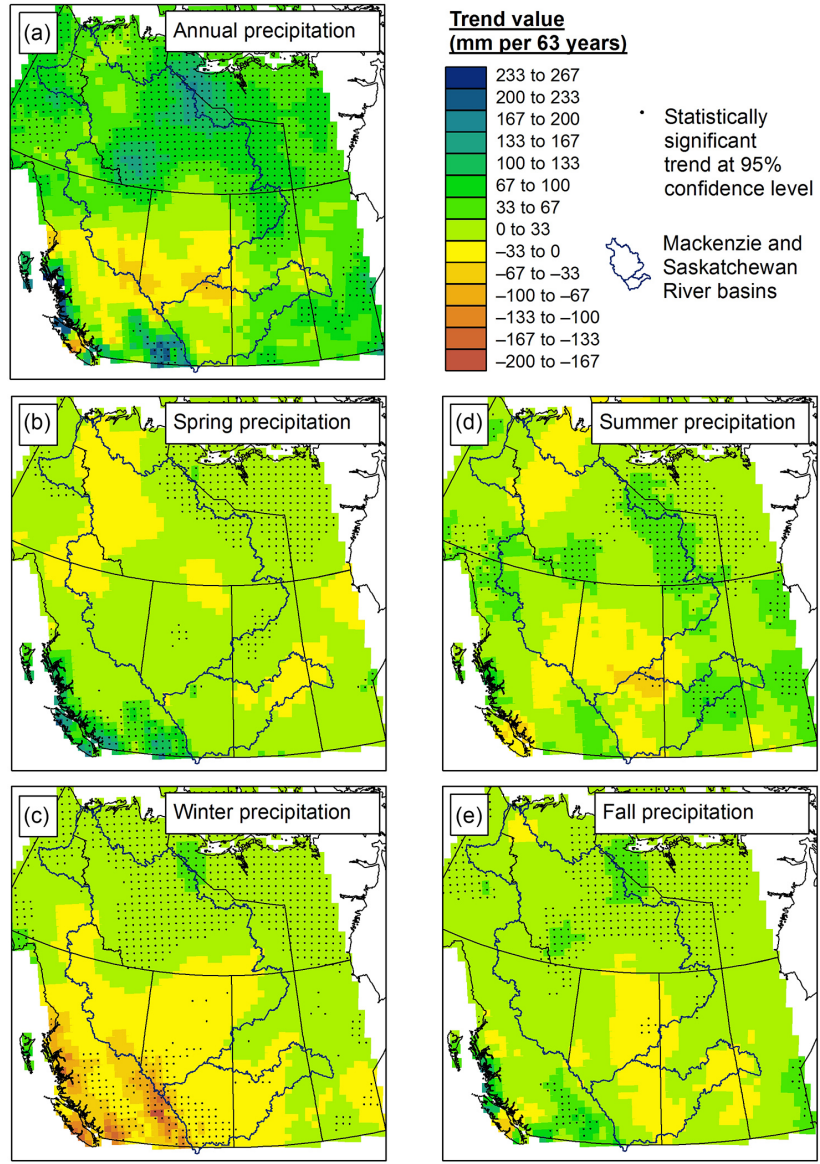

Figure 5. Spatial patterns of trends (millimetres per 63 years) in annual and seasonal totals of precipitation over the period 1950-2012 across western Canada, based on analysis of CANGRD precipitation data.

the southern Mackenzie basin and most of the Saskatchewan basin it has decreased by about 20-30\% (and as much as $50 \%$ or more in southern Alberta) (Fig. 4c). Absolute changes are mostly within about $\pm 30 \mathrm{~mm}$, except over the southern mountain areas (Fig. 5c). Again, caution needs to be used as there is a low density of stations in much of the north and most observing stations in the mountain areas tend to be located at low elevation and may not be representative of higher-elevation areas.

In addition to changes in the amount of precipitation, there have also been observed shifts in its phase. Zhang et al. (2000) and Vincent et al. (2015) examined trends in the ratio of annual and seasonal snowfall to precipitation totals; from 1948 to 2012, this ratio decreased over southwestern Canada (from 0 to $15 \%$ ) and increased over much of northern Canada (by 5-20\%). The greatest changes occurred in spring over the western half of the country, with widespread reductions of up to $20 \%$ or more, reflecting the effects of warmer temperatures. Mekis and Vincent (2011) separately examined annual and seasonal trends in both rainfall and snowfall. They found that over the past 60 years, rainfall totals have increased annually and in all seasons with the most pronounced change during spring, with increases of between 30 and $50 \%$ over much of western Canada. Annual snowfall amounts had decreased across most of southwestern Canada (reductions of 10-30\%) but increased in much of the north (by up to $30 \%$ ), with the greatest changes occurring during winter and spring (reductions of up to $50 \%$ in the southwest and increases up to $50 \%$ for some northern stations).

Precipitation variability here is linked to large-scale modes of atmospheric-oceanic circulation, including ENSO, PDO, $\mathrm{NAO}$, and others. El Niño and La Niña events tend to be associated with distinct negative and positive winter precipitation anomalies over southwestern Canada (Shabbar et al., 1997; Gan et al., 2007), while positive/negative phases of the PDO tend to be associated with drier/wetter than normal winters (Whitfield et al., 2010). Bonsal and Shabbar (2008) and Whitfield et al. (2010) provide useful summaries of the influence of these modes on the hydro-climatology of western Canada. While they play an important role in the interannual to inter-decadal variation of precipitation, longer-term trends appear to be mainly independent of this influence. For example, Vincent et al. (2015) assessed trends in annual and seasonal total precipitation and snowfall ratio after removal of the influence of PDO and NAO indices and found that the combination of these indices explained less than $10 \%$ of the trends over 1948-2010 and 1900-2012.

\subsection{Changes in daily and extreme precipitation}

Aspects of the seasonality, frequency, duration, and intensity of precipitation events have changed over the region in recent decades. For the period 1950-2003, Vincent and Mekis (2006) reported more days with precipitation and especially with rainfall (10-30 days per year over the period) and a decrease in average daily intensity (i.e., total annual precipitation divided by number of days with precipitation; $\left.0-3 \mathrm{~mm} \mathrm{day}^{-1}\right)$. Other indices characterizing extreme heavy precipitation events and maximum annual dry spells did not show clear patterns or statistically significant trends. Stone et al. (2000) used station-dependent thresholds to classify event intensity and found that during the latter half of the 20th century, the frequency of lighter events decreased while that of intermediate and heavier events increased, respectively, by up to a few percent per decade. Zhang et al. (2001b) defined heavy rainfall and snowfall events for each season using a threshold value that is exceeded by an average of three events per year. Temporal variations of regional heavy precipitation displayed strong inter-decadal variability with limited evidence of long-term trends over the latter part of the 20th century, except in the number of heavy snowfall events in fall and winter, which increased over all of northern Canada. Mekis et al. (2015) found little evidence of changes in heavy rainfall events (accumulated rainfall $>10,25$, and $50 \mathrm{~mm}$ over periods of 1,24 , and $48 \mathrm{~h}$, respectively) for the region 
over the period 1960-2012. They noted that there is no apparent regional pattern in such extreme events because they are highly localized and the station density is relatively low. Looking at the hydrological character of rainfall, Shook and Pomeroy (2012) examined trends in short duration convective events, multiple day accumulations, and rainfall occurring during the spring and fall over the Canadian prairies. Over the periods 1901-2000 and 1951-2000, the fraction of summer rainfall from convective events has decreased at many locations, while that from multiple-day events has increased significantly.

\subsection{Drought}

There have been a number of severe prairie droughts documented over the instrumental record, with multi-year droughts occurring in the 1890s, 1930s, late 1950s and early 1960s, 1980s, and 2000s (Bonsal and Regier, 2007; Bonsal et al., 2011). In the first half of 2015, much of western Canada was experiencing abnormal to record dry conditions - in many areas immediately following a several-year period of historical record wetness and flooding. This led to widespread forest fires, low water levels in streams, lakes, and reservoirs and low soil moisture levels, and it was unusual in that it stretched over a vast area from Mexico to Alaska. Since the beginning of the 20th century there has been decadal-scale variability in drought occurrence as indicated by various precipitation and soil moisture indices, but there has been no consistent long-term trend in drought frequency or magnitude (Millett et al., 2009; Qian et al., 2010; Bonsal et al., 2013). This variability has tended to coincide primarily with precipitation variations modulated by largescale modes of oceanic-atmospheric circulation (Bonsal et al., 2011; Shabbar and Skinner, 2004; Bonsal and Shabbar, 2008). Through the use of proxy information it appears that extended drought conditions during the 20th century have been relatively mild in comparison to the pre-settlement era on the prairies, and there is evidence of climate-driven nonstationarities in hydrological variables over the past several centuries or millennia (Bonsal et al., 2013; Razavi et al., 2015). Bonsal et al. (2011) provide a useful review of drought research in Canada. The recently completed DRI network was established to conduct a comprehensive study of the severe 1999-2005 Canadian prairie drought (Hanesiak et al., 2011; Stewart et al., 2011).

\section{Seasonal snow cover}

\subsection{Context}

The seasonal snow cover that forms over the landscape during the winter months is an important feature influencing the climate, hydrology, and ecology of cold regions and mountainous areas (Male, 1980; Gray and Male, 1981). For instance, it has a strong control on the surface energy ex- change with the atmosphere, represents an important storage of water that is released during the spring melt period, and affects ground thermal regimes and surface vegetation through its insulating properties. Changes and variability in snow cover therefore have a large impact on many other Earth system processes in these regions, and feedbacks with the climate system can intensify local and regional patterns of change and have global implications (Callaghan et al., 2011b). Snowpack evolution is closely linked with climatic elements such as air temperature and precipitation, and interannual variations and trends in snow cover conditions coincide strongly with those of such climate variables.

\subsection{Snow cover data sets}

The Meteorological Service of Canada (MSC) has produced the Canadian daily snow depth database and the SWE database, based on in situ observations of surface snow cover at climatological stations across Canada and at snow course locations (MSC, 2000). Brown and Braaten (1998) describe the snow depth database, including quality control procedures for internal consistency, the effects of station shifts and urban warming, and the reconstruction of missing values. The data represent about 400 stations with varying record lengths, few of which began before the mid-1940s, while the spatial density and record length tend to decrease considerably in the north. The measurements also tend to be biased to low elevations and open areas (Brown and Braaten, 1998). The SWE database contains weekly, biweekly, or monthly measurements by a number of agencies, but since the late 1990s it has not been actively maintained; in many cases, updates to snow course data can readily be obtained from the various provincial/territorial agencies involved (MSC, 2000). The data primarily cover the period from about 1950 to the mid-1990s, with a pronounced decline after 1985.

Remotely sensed snow cover data sets provide a useful source of information, supplementing in situ observations and extending coverage over broad regions (Hall et al., 2006). Brown et al. (2010), Frei et al. (2012), and Kelly (2012) describe some of the more widely used satellite and model-derived snow cover products. The longest time series is the National Oceanic and Atmospheric Administration (NOAA) weekly snow cover product, which includes near-consistent snow cover mapping since 1966 (Robinson et al., 1993). NASA's Moderate Resolution Imaging Spectroradiometer (MODIS) also provides a range of valuable snow cover products, although data availability is only from 1999 (Hall et al., 2002; Hall and Riggs, 2007). Coarse resolution and classification thresholds lead to uncertainty in these products, particularly in mountain regions (e.g., Brasnett, 1999; Brown et al., 2010). Passive microwave sensors such as the Scanning Multichannel Microwave Radiometer (SMMR), Special Sensor Microwave/Imager (SSM/I), and Advanced Microwave Scanning Radiometer, EOS (AMSRE), provide information on snow depth, SWE, and melt onset 
but are limited by variations in snowpack physical properties and wetness that affect the signal, low spatial resolution that does not capture local-scale accumulation, and restrictions associated with both shallow or intermittent snow and deep snow (> 120-150 mm SWE) (Frei et al., 2012; Kelly, 2012).

\subsection{Changes in snow cover}

Over most of Canada there has been a pattern of deceasing snow depths and snow cover duration and extent since the mid-1970s, with the largest declines in western Canada and proportionally greater changes later in winter and spring (Brown and Braaten, 1998; Dyer and Mote, 2006; Derksen et al., 2008; Derksen and Brown, 2012). Brown and Braaten (1998) analyzed the Canadian daily snow depth database for the period 1946-1995 and found widespread and spatially coherent decreases in depth that increased in magnitude and spatial extent from January through March. Maximum changes were found over western Canada, where reductions of between 1.0 and $1.5 \mathrm{~cm}$ year $^{-1}$ were observed. Decreases during the fall were not as widespread or as great in magnitude. Analyses of remotely sensed data support these observations and show that interannual variations of snow cover extent are highly correlated over broad regions in western Canada (Frei and Robinson, 1999; Robinson and Frei, 2000). Using the NOAA weekly snow cover product, Déry and Brown (2007) reported that over the period 1972-2006, the weekly mean trend in snow cover extent was $-0.78 \times 10^{6} \mathrm{~km}^{2}$ (35 years) ${ }^{-1}$ for North America and that the trends were amplified further northward, consistent with a surface albedo-snow cover extent feedback reinforcing the anomalies. Brown et al. (2010) analyzed 10 separate snow cover data sources covering different periods between 1967 and 2008 and showed that, over this period, May and June snow cover extent has exhibited a considerable decline, decreasing by 14 and $46 \%$ respectively across the panArctic region, primarily as a result of earlier snowmelt and snow cover depletion. Several studies have shown trends toward both earlier melt onset and shorter overall melt duration over North America since at least 1960 (Dyer and Mote, 2007; Tedesco et al., 2009). Derksen and Brown (2012) used the NOAA snow cover record and showed that successive records for the lowest North American June snow cover extent were set in 3 of the last 5 years between 1967 and 2012.

To illustrate the pattern over western Canada, Fig. 6 shows recent trends in snow cover duration from the Canadian daily snow depth data set (1950-2012; Fig. 6a) and the NOAA weekly snow cover product (1972-2013; Fig. 6b). Trends were computed using the method of Zhang et al. (2000) described above, with significance assessed at the $95 \%$ confidence level. The magnitude of trends in annual snow cover duration have ranged from about 1 to 15 fewer days decade ${ }^{-1}$, with an average decline of about 4 days decade ${ }^{-1}$, almost entirely due to reductions occurring during the spring season (Brown et al., 2010; R. Brown, per-
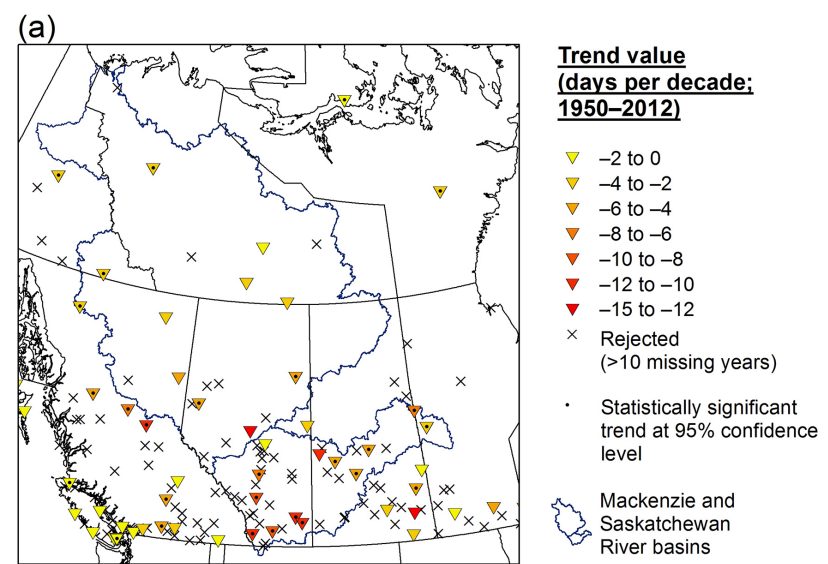

(b)
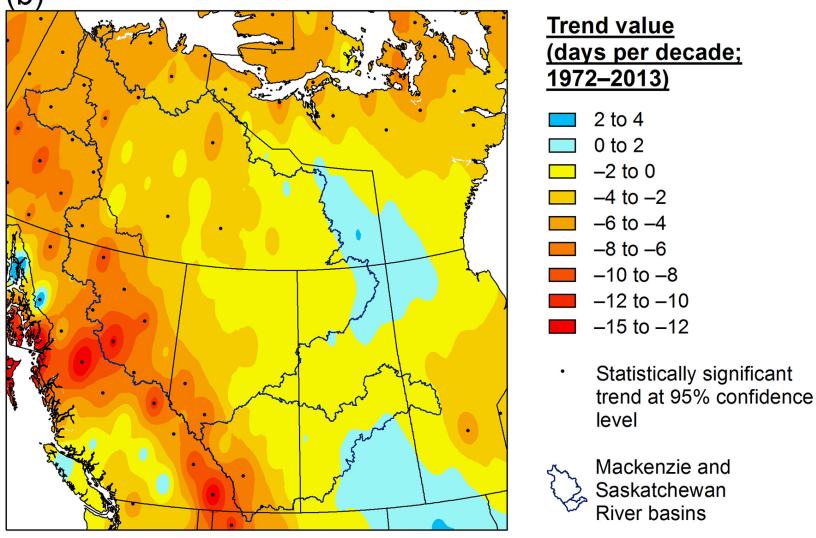

Figure 6. (a) Trends in annual snow cover duration for the period 1950-2012 based on surface observations as part of the Canadian daily snow depth data set. Stations were rejected in cases where the amount of missing data exceeded 10 years. (b) Trends in spring season (February-August) snow cover duration for the period 1972-2013 based on the NOAA weekly snow cover product from the Rutgers University data set (Rutgers data documentation at http://climate.rutgers.edu/snowcover/docs.php?target=vis). In (b), the spatial patterns are based on inverse distance weighting of the points in a $190.5 \mathrm{~km}$ polar stereographic grid. Data and results provided by R. Brown, Environment Canada.

sonal communication, 2014). This equates to a shortening of the snow cover period from 1 to 2 months over the region since 1950. The results in Fig. 6a and b differ somewhat in magnitude and spatial pattern, due in part to differences in data sets and temporal periods, but generally point to greater changes in the southern and western parts of the Mackenzie and Saskatchewan River basins and lesser change in the northeastern Mackenzie basin (also reported by Derksen et al. 2008). It is noted that snow cover trends in the mountain regions from both in situ and remotely sensed data are generally more uncertain due to the low elevation bias of climate stations and the coarse resolution of satellite imagery.

At regional to continental scales, snow cover trends are mostly associated with pervasive climate warming patterns independent of low-frequency atmospheric circulation pat- 
terns and teleconnections (Derksen and Brown, 2012). Ge and Gong (2009) noted that at these scales, the regional domain of climate mode teleconnections is exceeded. More locally, certain modes of variability (e.g., ENSO, PDO, NAO) influence the interannual variability of snow cover (Derksen et al., 2008; Ge and Gong, 2009; Bao et al., 2011) but are not the main driving factor behind the decreasing trends in western Canada. For instance, Vincent et al. (2015) noted that trends in various snow cover indices from the Canadian daily snow depth data set were almost identical after removal of the influence of PDO and NAO.

Detecting regional changes in SWE is more challenging due to difficulties in estimating variable snow density and problems retrieving SWE information from microwave sensors, and robust information on large-scale, long-term SWE trends from satellite data is not available (Kelly, 2012). Brown (2000) used a combination of in situ snow course and synoptic station snow depths, along with NOAA weekly snow cover data to reconstruct monthly SWE for the period 1915-1997 over North America. He found overall statistically significant increasing trends in SWE for December, January, and February and a significant decrease in April, but he did not provide details on regional patterns. Some work has examined SWE variations over western Canada using SMMR and SSM/I data (Walker and Silis, 2002; Derksen et al., 2002, 2003; Tong et al., 2010), but the analysis periods were relatively short and clear trends could not be detected. Derksen et al. (2004) combined SMMR and SSM/I with in situ SWE observations over the provinces of Saskatchewan and Manitoba and several states in north-central USA to examine SWE variability from 1915 to 2002 . Derksen et al. (2008) used in situ observations, NOAA weekly snow cover, and SMMR and SSM/I SWE retrievals to examine trends over the Mackenzie River basin from 1950 to 1999. In both studies, monthly SWE in spring did not show clear long-term trends but rather indicated decadal-scale variability that varied regionally. Squires (2014) focused on a more limited part of the Mackenzie basin around the Great Slave Lake region using snow course data collected by Aboriginal Affairs and Northern Development Canada to assess trends in snow depth and SWE from the mid-1960s up to 2010. They reported progressively earlier onset of snowmelt across most of this area, along with regionally varying changes in maximum SWE.

\section{Mountain glaciers and ice fields}

\subsection{Context}

Mountain glaciers represent a major geomorphic agent shaping the landscape, directly affect local surrounding climatic conditions, and provide a source of runoff well beyond the spring snowmelt freshet period (Moore et al., 2009). Glacier mass balance responds directly to variations in snow accu- mulation and snow and ice ablation, as influenced by air temperature, precipitation, radiation, and other meteorological variables, while extended perturbations in the mass balance tend to produce a delayed response in glacier geometry, surface elevation, and terminus position (Oerlemans, 1989). Thus, patterns of glacier behaviour over time provide a proxy indicator of the local to regional prevailing climatic conditions. Globally, mountain glaciers have predominantly been losing mass and retreating, and there is concern that as this continues their ability to provide a reliable source of meltwater runoff during the summer and fall period will be reduced (Radić and Hock, 2014). In western Canada, glacier runoff has been shown to provide a buffering mechanism during extremely dry years (Hopkinson and Young, 1998; Comeau et al., 2009), but as glacier cover diminishes they may no longer be able to effectively augment low flows (Demuth and Pietroniro, 2003; Marshall et al., 2011).

\subsection{Glacier inventories and mass balance data}

Glaciers and ice fields occur extensively throughout the mountain regions of western Canada, covering an area of roughly $50000 \mathrm{~km}^{2}$ and including almost 12000 individually documented ice masses (Ommanney, 1980, 2002a; Fig. 7). The Canadian Glacier Inventory project was initiated as an International Hydrological Decade (IHD) contribution in the late 1960s and led to the production of the Glacier Atlas of Canada, which includes detailed maps identifying all known glaciers, catalogued by Water Survey of Canada (WSC) drainage basins. Ommanney (1980, 2002b) describe the inventory and the procedures used; digital versions of the original maps can be accessed through the GeoGratis website (http://geogratis.cgdi.gc.ca/). More recent work has updated and extended this inventory over parts of western Canada, contributing to the Global Land Ice Measurements from Space (GLIMS) project (Bolch et al., 2010; Demuth et al., 2014).

Detailed in situ observations and mass balance records are available only for a very limited number of glaciers over the region. Ommanney (2002a) and Østrem (2006) provide accounts of the history of glaciological investigations in western Canada and the selection of reference mass balance glaciers. The most well-documented and studied glacier in the region is Peyto Glacier (Fig. 7), which has been documented since the late 1800s and has near continuous annual and seasonal mass balance records going back to 1965 , beginning as part of the IHD activities (Østrem, 2006; Demuth and Keller, 2006). In contrast, monitoring activities at most other glaciers have been short-lived and are largely discontinued. A concern for ongoing initiatives is the retreat and disintegration of glacier termini, making access difficult and restricting continuity of measurement programmes. 

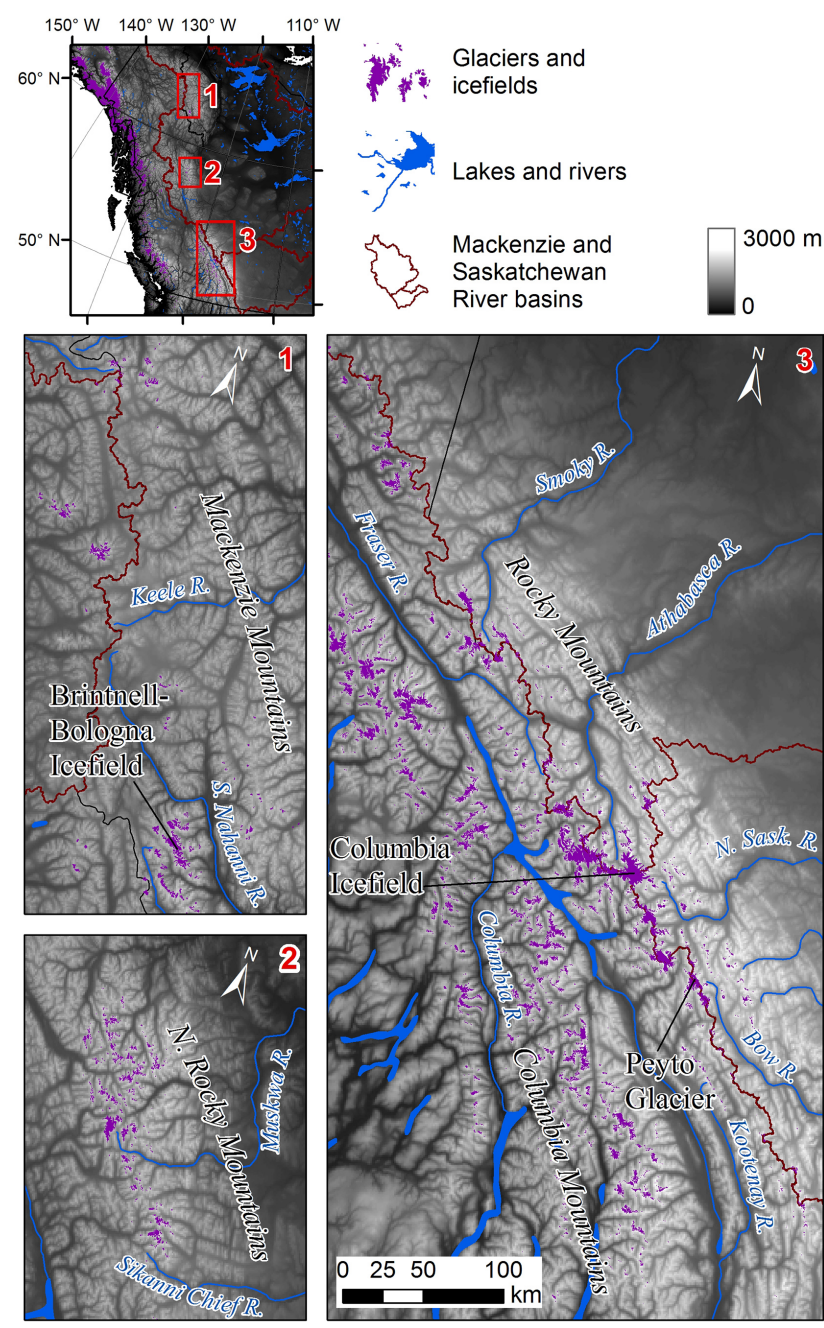

Figure 7. Map of western Canada showing the distribution of glaciers and ice fields within the major interior mountain ranges; the locations CCRN glacier observatories are indicated. Glacier extents are from the GLIMS database (www.glims.org/) and the North American Environmental Atlas (http://www.cec.org/sites/default/ atlas/map/).

\subsection{Glacier changes}

Glaciers across western North America have predominantly retreated over the past century and the observational records have shown mostly negative net mass balances (Moore et al., 2009). As shown in Fig. 8, the net annual mass balance of Peyto Glacier has exhibited strong interannual variations but has been mostly negative since 1965 (average $-580 \mathrm{~mm}$ water equivalent, w.e.); from 1965 to 2012 the cumulative mass balance has indicated a loss of over $27 \mathrm{~m}$ w.e. averaged over the glacier (Demuth and Keller, 2006; M. Demuth, personal communication, 2014). Demuth and Keller (2006) noted that the annual mass balance is mainly driven by variations in winter balance and that a shift to primarily negative net balance after 1976 was driven mainly by a reduction in winter

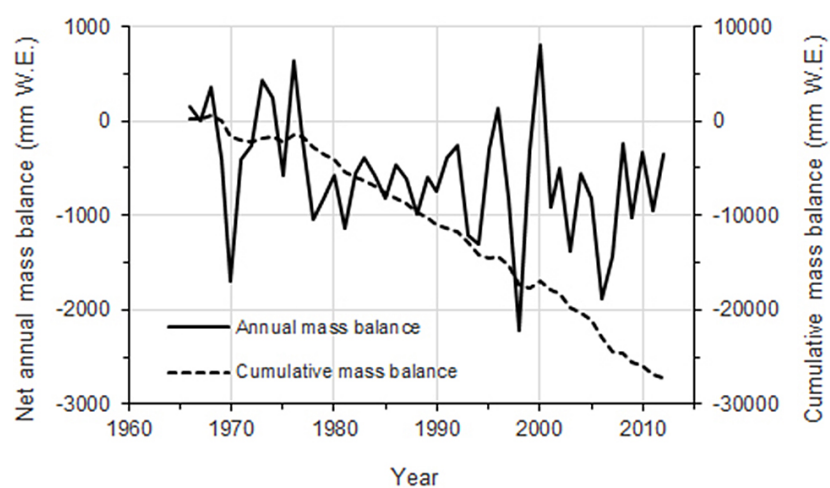

Figure 8. Net annual mass balance series for Peyto Glacier (19662012) and cumulative mass balance over the 46-year period. Note that values in 1991/92 are reconstructed from proxy information and values in 2010-12 are preliminary (data provided by M. Demuth, Geological Survey of Canada).

snowfall in association with the shift in the PDO index to warm phase. Since the end of the Little Ice Age (LIA) in the 19th century - when most glaciers were at their maximum Holocene extent - Peyto Glacier has retreated by about $3 \mathrm{~km}$, and in recent years a large pro-glacial lake has formed at its terminus. Most valley glaciers in the Rocky Mountains have retreated by $1-2 \mathrm{~km}$ since the end of the LIA (Ommanney, 2002c).

The rates of retreat have varied, with initially rapid rates in the first half of the 20th century, followed by a short-lived period of stabilization or advancement until 1980 and continuing retreat since then (Moore et al., 2009). The records at the Athabasca and Saskatchewan glaciers, together with observations elsewhere in the Rockies, show a sharp decline in glacier recession in the 1960s and 1970s, attributed to a shortlived period of positive net mass balance (Luckman, 1998). McCarthy and Smith (1994) documented historical glacier length variations within the southern Rockies and showed that individual glaciers displayed a wide range of patterns, with some stabilizing after the 1950s, others slowing in their rate of retreat, and still others exhibiting an accelerated recession beginning in the last few decades of the 20th century.

Glacier area changes have been investigated in many recent studies and, at the regional scale, have been reported to have declined from as little as $11 \%$ over 53 years to as much as $29 \%$ over 13 years, with most studies reporting about a $25 \%$ decline in glacier cover since the mid- to late 20th century (Hopkinson and Young, 1998; DeBeer and Sharp, 2007; Schiefer et al. 2007; Demuth et al., 2008, 2014; Jiskoot et al., 2009; Bolch et al., 2010; Tennant et al., 2012; Tennant and Menounos, 2013; Beedle et al., 2015). Individually, glaciers have exhibited a wide range of local changes from small net advances to complete disappearance, reflecting the strong control of local factors on glacier mass balance, dynamics, and response. A number of features have been commonly reported in western Canada: (1) glaciers have gener- 
ally been continuing to lose mass and retreat, and rates of loss have accelerated in the last few decades; (2) smaller glaciers have tended to exhibit greater variability in their relative area changes, while larger glaciers have exhibited more consistent and moderate relative changes; and (3) collectively most of the glacier area loss has been due to the retreat of larger glaciers that comprise a greater proportion of the regional ice cover.

Volumetric changes have been measured through comparison of repeat digital elevation models, which has indicated thinning rates from about 0.5 to $0.9 \mathrm{~m} \mathrm{year}^{-1}$ (Schiefer et al., 2007; Tennant and Menounos, 2013). Hopkinson and Demuth (2006) used repeated airborne lidar (light detection and ranging) measurements at Peyto Glacier and found that in a period of just under 2 years, the glacier's surface had thinned by about $3.5 \mathrm{~m}$ on average and the glacier had lost $33 \times 10^{6} \mathrm{~m}^{3}$ of ice. Schiefer et al. (2007) found that glacier volume in the Rockies declined by about $17 \mathrm{~km}^{3}$ over the period 1985-1999. Marshall et al. (2011) used an empirical volume-area scaling relationship (e.g., Chen and Ohmura, 1990) and volume approximations based on glacier surface slope, and they estimated the present volume of glaciers in the eastern slopes of the Rocky Mountains to be $55 \pm 15 \mathrm{~km}^{3}$, corresponding to an average glacier thickness of $57 \mathrm{~m}$.

\subsection{Contributions to river discharge}

In western Canada, several recent studies have compared glacier losses with observed discharge and used various modelling approaches to estimate the proportional contribution by glaciers (Hopkinson and Young, 1998; Comeau et al., 2009; Marshall et al., 2011; Jost et al., 2012; Naz et al., 2014; Bash and Marshall, 2014). Glacier wastage, referring to ice loss as a result of any negative net mass balance, has been found to account on average for about $1-5 \%$ of the annual discharge of the larger rivers exiting the eastern slopes of the Rockies and up to $10 \%$ or slightly more of the summer (July-September) flow (Comeau et al., 2009; Marshall et al., 2011; Bash and Marshall, 2014). In an extremely low flow year, Hopkinson and Young (1998) found that glacier wastage supplied $13 \%$ of the annual flow of the Bow River at Banff, with a maximum monthly contribution in August of $56 \%$. Jost et al. (2012) found that glacier ice melt (excluding seasonal snow cover) supplied an average of $6 \%$ of the annual flow of the upper Columbia River between 1970 and 2007, which increased to as much as 25 and $35 \%$ of August and September flow. Naz et al. (2014) simulated glacier contributions to the upper Bow River basin over 1981-2007. Their results indicated that while summer and annual glacier melt showed increasing tendencies, summer and annual discharge showed decreasing tendencies. They speculated that the decline in discharge is associated with a combined effect of decreases in glacier cover and precipitation. Demuth and Pietroniro (2003) observed that the discharge from glacierized catchments in the North Saskatchewan River basin dur- ing the transition-to-baseflow (TBF) period has decreased since the mid-20th century, despite increasing precipitation during the TBF period and greater ice melt. This response is commensurate with reductions in glacier area. They also observed an increase in the variability of discharge during the TBF period, pointing to a reduction in the buffering capacity of glaciers in this system.

\section{Permafrost}

\subsection{Context}

Permafrost, defined as ground that remains at or below a temperature of $0{ }^{\circ} \mathrm{C}$ for at least 2 consecutive years, is a pervasive feature across approximately half of the Canadian land mass (Smith, 2011). At its southern limits in Canada it occurs as sporadic and discontinuous permafrost with annual temperatures near $0{ }^{\circ} \mathrm{C}$, closely corresponding with the mean annual air temperature isotherm of $0^{\circ} \mathrm{C}$ (Burn, 2012), and it transitions to continuous, deep, and colder permafrost with increasing latitude (Fig. 9). The seasonal thawing of the upper "active layer" is linked with air temperature during the summer as well as the preceding winter (Smith et al., 2009; Burn and Zhang, 2010), while deep snow cover acts as an effective insulator, reducing heat loss and leading to warmer ground temperatures compared to areas with a thin snow cover in winter (Burn et al., 2009). Permafrost distribution and behaviour is also strongly linked to vegetation characteristics as these influence the surface energy balance, snow accumulation, and soil thermal properties (Burn, 2012). From a global perspective, permafrost-underlain watersheds, particularly those at or near $0^{\circ} \mathrm{C}$, are extremely sensitive to warming as changes in ground thermal status will alter all components of the hydrological cycle due to increases in subsurface storage for liquid water (Woo, 2012). This also impacts forest ecosystems and function, leading to thaw-induced collapse of forested peat plateaus and the loss of forest across vast parts of the boreal forest (Baltzer et al., 2014).

\subsection{Permafrost monitoring in Canada}

Two of the largest monitoring networks are maintained by the Geological Survey of Canada (GSC) and the Centre d'études nordiques, Université Laval. The GSC, in collaboration with other partners, has been developing and maintaining a network of sites that contribute to the Canadian Permafrost Monitoring Network as well as the Circumpolar Active Layer Monitoring (CALM) programme and the Global Terrestrial Network for Permafrost (GTN-P), providing long-term measurements of permafrost thermal state and active layer conditions. About 75 sites operated by government and university scientists contribute to these networks, with more than 20 boreholes available since the mid-1980s of up to $20 \mathrm{~m}$ depth in the Mackenzie River valley and delta in the Northwest Territories (Fig. 9; Smith et al., 2005). A 


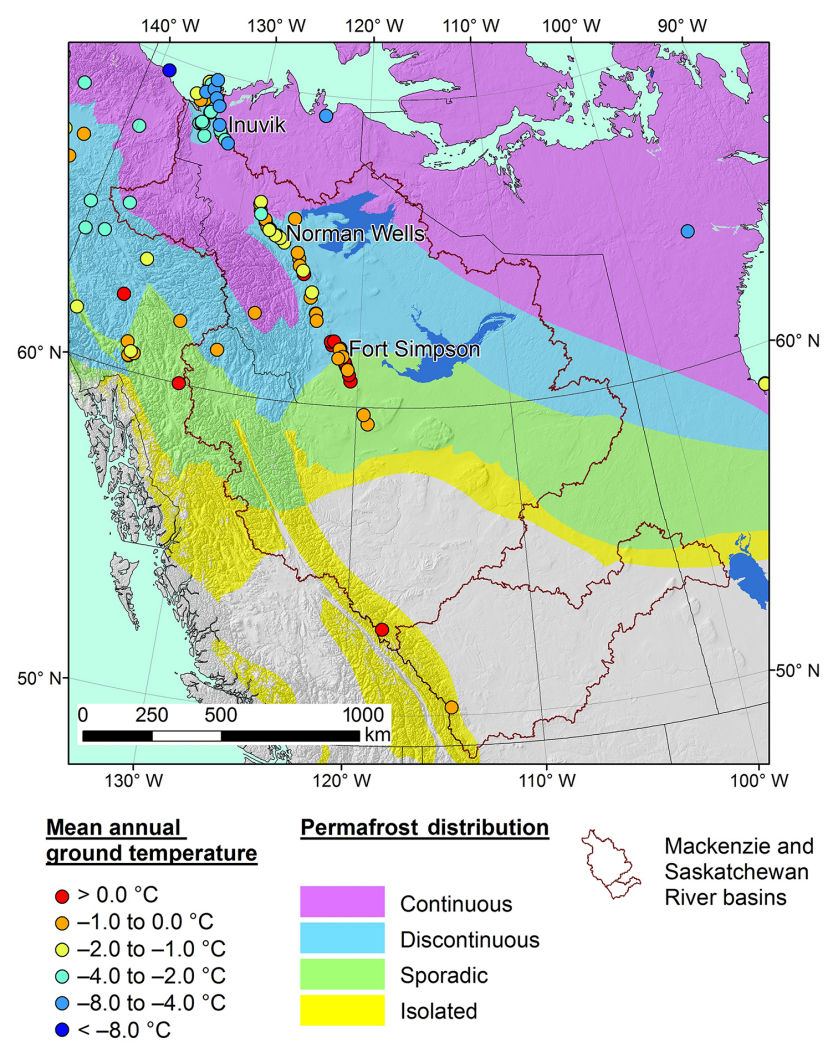

Figure 9. Distribution of permafrost over western Canada (from Brown et al., 2001) and mean annual ground temperature (MAGT) recorded during the IPY (2007-2009) (from IPA, 2010).

number of additional monitoring sites were established during the IPY period 2007-2009, bringing the total number of sites in North America up to 350 (Smith et al., 2010). The distribution of these sites tends to be along roads and pipelines, while the boreholes themselves vary in depth, measurement technique, and recording frequency; the network, however, provided a useful snapshot of permafrost in northern North America for the IPY period (Smith et al., 2010). It is important to note that for all ground temperature and active layer thickness data, local site characteristics and conditions can have a considerable influence on the variability of permafrost conditions (e.g., Burgess and Smith, 2003; Smith et al., 2009). Useful reviews of permafrost conditions and their recent changes over northern Canada are provided by Smith (2011), Burn (2012), Derksen et al. (2012), and Bush et al. (2014).

\subsection{Changes in permafrost}

Observations from monitoring sites across northern Canada have shown that ground temperatures to depths of 10-15 m or more have been increasing in response to recent climate warming (Smith et al., 2005, 2010). The magnitude of this warming has varied with latitude, generally exhibiting greater trends in the northern continuous permafrost zone and more limited temperature change in the southern discontinuous and sporadic zones, where permafrost thaw has been widespread. Smith et al. (2005) and Smith (2011) presented temporal variations in permafrost temperature from the Canadian Permafrost Monitoring Network and the GTNP. They showed that in the southern Mackenzie Valley, where permafrost is warmer than $-0.3{ }^{\circ} \mathrm{C}$ and only about $10 \mathrm{~m}$ thick, there has been no significant warming of permafrost in the last few decades (less than $0.1^{\circ} \mathrm{Cdecade}^{-1}$ ). It was noted that the absence of trends is probably due to phase change/latent heat effects restricting further warming. A similar pattern was observed for warm permafrost in the Takhini River valley, southern Yukon (Burn, 1998). Further north in the central and northern Mackenzie region, warming of shallow permafrost of between 0.3 and $0.6^{\circ} \mathrm{C} \mathrm{decade}^{-1}$ has occurred since the mid-1980s (Smith et al., 2005; Smith, 2011), consistent with the increasing air temperature trends over the same period (cf. Fig. 3). In the Mackenzie Delta area, permafrost warming has been significant, but locally variable. For instance, Burn and Kokelj (2009) compared permafrost temperatures here in the 1960s and early 1970s with those based on data collected during 2003-2007. They showed that near-surface ground temperatures had increased over that time by about $1-2^{\circ} \mathrm{C}$ in the tundra uplands to the east of the delta and by $0.5-1{ }^{\circ} \mathrm{C}$ in the delta itself south of the tree line, where greater snow depth may have reduced the sensitivity to climate warming.

As ground temperatures have risen, there has also been an increase in the thaw depth of the seasonal active layer across northern Canada and local to widespread permafrost degradation in the discontinuous permafrost zone (Smith, 2011). In many areas, the melting of the near-surface ground ice has resulted in decreased stability and strength of the substrate, leading to surface subsidence and waterlogging of soils (both of which further amplify permafrost thaw), thermokarst development, and collapse of forested peat plateaus (Jorgenson et al., 2008; Smith et al., 2008; Baltzer et al., 2014). Burn and Kokelj (2009) reported interannual variability of maximum seasonal thaw depths that ranged between 0.3 and $0.55 \mathrm{~m}$, with a trend toward increasing thaw depths of $0.08 \mathrm{~m}$ over the period 1983-2008 in the outer Mackenzie Delta area. Smith et al. (2009) examined summer thaw depths over $100 \times 100 \mathrm{~m}$ probing grids at various CALM sites along the Mackenzie Valley and found that intra-site variability can be high with substantial variation in active layer depths where surface organic soils and moisture content are high and spatially variable. Their 8-year (1998-2005) study period was too short to detect temporal trends, but they were able to relate grid mean thaw depths to late-summer thawing degree days on a site-by-site basis, and they showed a latitudinal tendency of increasing maximum thaw depth southward. Burgess and Smith (2003) demonstrated that rates of increasing thaw depth were generally greatest in the first 7-8 years after disturbance at sites along a pipeline corridor between 
Norman Wells and northern Alberta. Permafrost thaw had continued, albeit at a slower rate, for at least 17 years after 1985, reaching depths of 3-4 $\mathrm{m}$ in colder lacustrine soils to over $7 \mathrm{~m}$ in coarse mineral soils. Further south, James et al. (2013) evaluated changes in permafrost in the southern discontinuous permafrost zone at 55 sites along the Alaska Highway from Fort St. John, BC, to Whitehorse, YT, and observed that at almost half of the sites where permafrost existed in 1964, it has since disappeared. Where permafrost remains, it has become patchy and thin $(<15 \mathrm{~m})$, has a greater active layer thickness, and has warmed to temperatures of between -0.5 and $0{ }^{\circ} \mathrm{C}$. Their results have indicated a northward shift in the limit of permafrost for this region.

Studies have examined changes in the spatial extent and connectivity of permafrost in the Taiga and Boreal Plains within the discontinuous zone and generally found that it is shrinking in area and becoming increasingly fragmented. Beilman and Robinson (2003) used historic aerial photos and recent satellite imagery to compare permafrost extent between about 1950 and 2000 and found that at peatland sites in the Northwest Territories, as much as $50 \%$ of permafrost had degraded and thawed, while in more southern locations in Alberta, Saskatchewan, and Manitoba, between 30 and $65 \%$ of localized permafrost has thawed. Similar analysis at the Scotty Creek Research Basin near Ft. Simpson (Quinton et al., 2011) showed that the extent of forest-covered permafrost plateaus had decreased by over $38 \%$ in localized areas between 1947 and 2008, with associated collapse of black spruce forest on the plateaus and an increasingly connected surface drainage network. This has the potential to substantially alter basin runoff production in the region (Connon et al., 2014). Further, it has been shown that the rates of permafrost and forested plateau loss have been accelerating, with the average rate of loss in seven different local areas of interest being over 3 times greater during the period 20002010 compared to 1977-2000 (Baltzer et al., 2014).

\section{Freshwater ice cover}

\subsection{Context}

Virtually all lake and river systems in the interior of western Canada are seasonally ice-covered, and this influences the timing and severity of low flows and floods associated with freeze-up and break-up periods (Beltaos and Prowse, 2009; Prowse, 2012) and has an important role in the ecology of these systems (Prowse, 2001; Prowse and Culp, 2003). Spatially, ice thickness ranges from skims in more temperate southern parts of this region to several metres in colder northern parts, while ice cover duration ranges from being a transient feature to existing for over 6 months of the year (Prowse, 2012). The formation and melt of the ice cover are sensitive to air temperature, precipitation, and other meteorological variables, which influence the composition, thick- ness, and stability of the ice (Beltaos and Prowse, 2009). In addition to thermal properties, river ice formation and breakup also depend on hydrodynamic processes that affect the mechanical properties of the ice (Beltaos, 2003). Ice cover thickness, timing (i.e., freeze-up and break-up), and duration therefore respond to changes in climatic conditions and other controls such as changes in terrestrial hydrologic regimes (Prowse et al., 2011a, b). Some useful reviews on the climatic controls, historical trends, and future projections of river ice formation and break-up are provided by Prowse and Beltaos (2002), Beltaos and Burrell (2003), Prowse and Bonsal (2004), Prowse et al. (2007), Beltaos and Prowse (2009), and Prowse (2012).

\subsection{Ice cover monitoring in Canada}

There are limited in situ records of ice cover variables over the interior of western Canada, which poses a challenge for systematic regional monitoring and assessment of ice cover regimes and their changes over time. Various observations on freshwater and coastal sea ice conditions in Canada have been gathered into a common database known as the Canadian Ice Database (CID) in order to aid climate monitoring efforts and improve numerical prediction models and remote sensing methods (Lenormand et al., 2002). The database contains records related to ice thickness and freeze-up and breakup dates for 757 sites across Canada (including 312 lakes and 288 rivers). During the late 1980s and 1990s, however, there was a drastic decline in the observation network and more recent observations only represent a very small percentage of those available in the mid-1980s. Lenormand et al. (2002) provide a complete description of the CID and its historical evolution. A volunteer monitoring program, IceWatch (www.naturewatch.ca/icewatch/), began in 2001 and builds on the CID.

\subsection{Changes in ice cover}

Observations have shown a general reduction in ice cover duration on lakes and rivers across much of Canada since the mid-20th century due primarily to earlier spring breakup (Prowse, 2012). Zhang et al. (2001a) and Burn and Hag Elnur (2002) analyzed trends in a number of hydro-climatic variables from the Canadian Reference Hydrometric Basin Network (RHBN) database (see next section) and found that the break-up of river ice and the spring freshet showed significant trends toward earlier occurrence at many sites in Canada over the latter half of the 20th century. The most pronounced changes were observed in western and southwestern Canada, with a greater degree of change over the last few decades of the century. Lacroix et al. (2005) used observations from the CID to examine spatial trends in river freeze-up and break-up over Canada and related these to the timing of the fall and spring $0{ }^{\circ} \mathrm{C}$ isotherms. They also found significant trends toward earlier spring break-up in 
this region over the latter part of the 20th century, while fall freeze-up patterns displayed greater regional variability and a mix of both increasing and decreasing trends. Strong correlations were found between break-up dates and the spring $0^{\circ} \mathrm{C}$ isotherms, but there were fewer significant associations between freeze-up and fall $0^{\circ} \mathrm{C}$ isotherms. Similar patterns were found by Duguay et al. (2006) for lake ice observations as part of the CID. Bonsal and Prowse (2003) showed that significant trends toward earlier spring $0^{\circ} \mathrm{C}$ isotherm dates have occurred over most of western Canada since 1950, whereas fall isotherm dates showed little change over most of Canada. Overall, the spatial and temporal trends in freeze-up and break-up closely correspond to those of surface air temperature (Prowse, 2012).

The magnitude of trends in ice cover formation, breakup, and overall duration has varied among studies, depending on data sets and temporal intervals of analysis. Lacroix et al. (2005) reported trends in river ice break-up over Canada ranging from 1.0 to 2.2 days earlier decade ${ }^{-1}$ and trends in freeze-up ranging from 1 day later to 0.1 days earlier decade ${ }^{-1}$, depending on the temporal analysis period (i.e., various periods between 1950 and 1998). In the Mackenzie River basin, de Rham et al. (2008) found earlier trends in spring break-up of about 1 day decade ${ }^{-1}$ in the upstream portions of the major tributaries over the period 19702002. Using a combination of in situ measurements and remotely sensed observations to examine lake ice phenological events, Latifovic and Pouliot (2007) found mostly earlier trends in lake ice break-up that averaged -2.3 days decade $^{-1}$ for the period 1970-2005 and mostly later trends in lake ice formation that averaged 1.6 days decade ${ }^{-1}$ for the same period. It has been noted that based on various northern cold region analyses, overall long-term increases in fall and spring air temperatures of $2-3{ }^{\circ} \mathrm{C}$ have been associated with a roughly 10-day delay in freeze-up and 15-day advance in break-up, shortening the ice cover period by almost a month in some cases (Prowse and Bonsal, 2004; Prowse et al., 2007).

Other characteristics of the seasonal ice cover are important, such as trends in the severity of river ice break-up events and ice thickness, but there have been few broad-scale analyses in Canada. In the Mackenzie Delta, a widespread tendency toward earlier break-up initiation and peak water level has been reported, associated with a tendency towards the occurrence of more ice-driven break-up events as opposed to discharge-driven events (Goulding et al., 2009). Ice-driven events are characterized by higher upstream backwater levels from ice jams and earlier break-up initiation of a more competent ice cover. It has been suggested that mid- to latespring air temperatures during the pre-break-up melt and runoff period more strongly influence the timing of break-up than overall winter temperatures and maximum ice thickness (Prowse and Bonsal, 2004). Prowse (2012) noted that the CID observations of Lenormand et al. (2002) over Canada do not show any obvious trends in ice thickness over the latter part of the 20 th century.

\section{River discharge}

\subsection{Context}

The flow of water in rivers and streams provides a vital water resource to society and serves an important ecological role; however, hydrological extremes represent serious potential risks and costs to society, such as during floods or droughts. River discharge represents the spatially integrated response to inputs from rainfall, snowmelt, and glacier melt, and its character is influenced by internal watershed storage capacity, vegetation, soils, topography, and other landscape features affecting the delivery of water to the stream channel network. In cold regions, the response to input events is highly sensitive to antecedent conditions in the basin, including preconditioning of soils, snowpacks, surface and subsurface water storage, and surface drainage network connectivity (Spence and Woo, 2008; Carey et al., 2010; Bring et al., 2016), while the nature of response is also dependent on the character of precipitation and the storm type (e.g., Shook and Pomeroy, 2012). The timing, magnitude, duration, and other characteristics of discharge are therefore closely linked with climate and other Earth system components, and they are sensitive to their changes within the watershed over multiple timescales.

\subsection{Canadian reference hydrometric basin network}

The WSC maintains a network of over 2000 hydrometric monitoring stations across Canada, and daily and monthly mean streamflow and stage levels are available through their hydrometric database (HYDAT; www.ec.gc.ca/rhc-wsc/). A subset of the long-term WSC observing stations was selected in the mid-1990s to characterize either pristine or stable hydrological conditions without significant impacts from flow regulation or upstream diversions and with good quality records for at least 20 or more years (Harvey et al., 1999). This subset comprises the RHBN in Canada, presently consisting of 217 active streamflow stations across the country with an average record length of over 50 years. The RHBN streamflow records are considered suitable for climate related studies while most other non-RHBN sites are likely to be affected by other non-climatic drivers (P. Whitfield, personal communication, 2014). Zhang et al. (2001a) and Burn and Hag Elnur (2002) provide detailed descriptions of the RHBN and the selection criteria used to include stations. In particular, a high level of accuracy was ensured by assessing the quality of data for each station with regard to the reliability of the stage-discharge relationship, stability of channel geometry, and reliability of water level and discharge measurement during ice-covered conditions (Zhang et al., 2001a). Whitfield et al. (2012) note that the RHBN 
records have been used in over 25 studies since the network was established, and they stress the importance of maintaining such reference hydrologic networks of long-term, quality time series data in relatively undisturbed regions.

\subsection{Changes in river discharge}

Many studies have examined variability and trends in the magnitude, timing, and other characteristics of river discharge over Canada (e.g., see Koshida et al., 2015; Mortsch et al., 2015). Direct comparison of the results is often difficult due to differences in temporal analysis periods, statistical methodology, region of focus, and data sets (i.e., RHBN and non-RHBN). Annual mean flow has been observed to vary regionally, with studies documenting both increasing and decreasing trends since the 1960s (Prowse et al., 2009b). Major river systems such as the Mackenzie and Nelson (which includes the Saskatchewan River system) have shown no detectable long-term trends at their mouths over this time (Woo and Thorne, 2003; Déry and Wood, 2005; McClelland et al., 2006; Déry et al., 2011), while statistically significant declines in annual flow have been observed for some smaller systems within these, such as the Athabasca River and its tributaries, and other rivers draining from the eastern slopes of the southern Rocky Mountains (Burn et al., 2004b; Rood et al., 2005; St. Jacques et al., 2010; Peters et al., 2013). Seasonally, a consistent pattern of increasing flow in the winter has been reported - especially for the Mackenzie River and many of its northern tributaries - with significant trends in the annual minimum discharge and lower flow percentiles (Burn et al., 2004b; Rood et al., 2008; St. Jacques and Sauchyn, 2009). Discharge rates during other times of the year have varied, but studies across the region have found decreasing trends in the annual maximum discharge rate and spring freshet flow volume (Burn et al., 2004b, 2008, 2010). Burn et al. $(2008,2010)$ have also reported increasing trends in the number of rainfall-runoff events later in summer and their peak magnitude, but little trend in runoff volume of these events.

To synthesize recent changes in flow across western Canada, we performed an analysis of monthly and annual discharge from RHBN records. Trends were computed for three different periods beginning in 1960, 1970, and 1980, and all ending in 2010. The analysis was restricted to currently active stations and excluded most higher-order rivers as these are mostly affected by upstream regulation and other human influences (and thus are not part of the RHBN). Missing data thresholds were set at no more than 3 days month ${ }^{-1}$ and 4 years in the analysis period, and records with missing data in excess of these limits were rejected. The MannKendall rank trend test (Mann, 1945; Kendall, 1975) was used, with significance assessed at the $95 \%$ confidence level, and trend slope was estimated based on the method of Sen (1968).
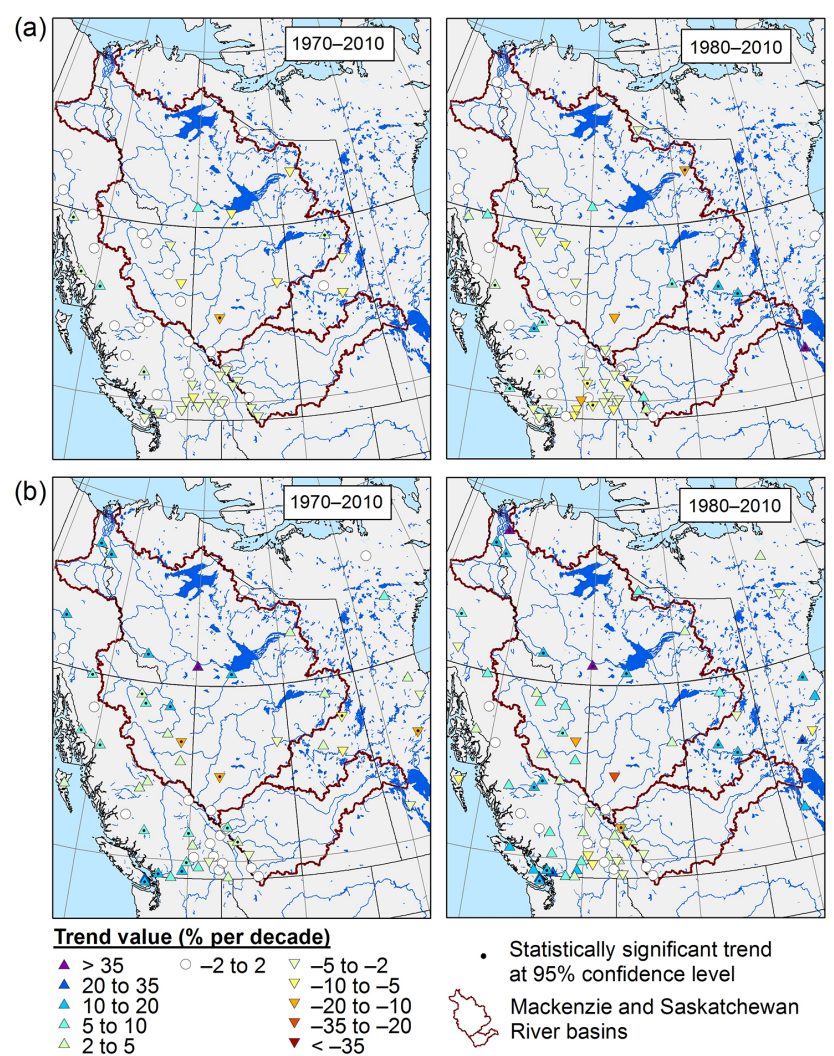

- Statistically significant trend at $95 \%$ confidence level

Shy Mackenzie and Saskatchewan Le River basins

Figure 10. Spatial patterns of trends in (a) annual discharge and (b) January discharge from RHBN stations over western Canada for the periods 1970-2010 and 1980-2010. Rejected stations are omitted.

Annual and January trend results are shown in Fig. 10. Trends since 1960 are not shown as most were rejected due to missing data. Annual flows exhibited a mixture of increasing and decreasing trends (Fig. 10a), while their magnitude, significance, and, in some cases, direction depended on the length of the analysis period. There is no well-defined regional pattern of consistent, long-term annual discharge change, except perhaps in the southern mountain regions of British Columbia and Alberta, where flows at a number of stations have decreased slightly over time. During the winter months there was a clear pattern of increasing flows across the north, with many stations exhibiting significant positive trends in all three periods (January flows in Fig. 10b provide a good example). Due to the low flow rates at this time of year, however, this has little influence on the annual mean flow of most rivers. In the southern half of the domain, trends in winter and spring discharge showed no consistent regional pattern, except later during summer and fall (not shown), when many streams and rivers in the North Saskatchewan and Peace-Athabasca River basins exhibited significant declining flows.

The most consistently reported characteristic of discharge trends across western Canada has been an earlier onset of the 
spring freshet since at least the mid-1960s, as indicated by features such as the initial hydrograph rise and the timing of peak spring flow (Woo and Thorne, 2003; Burn et al., 2004a, b, 2008, 2010; Burn, 2008; Abdul Aziz and Burn, 2006; Rood et al., 2008; Cunderlik and Ouarda, 2009). Woo and Thorne (2003) reported that between 1973 and 1999 the date of spring hydrograph rise for the Mackenzie River and several of its major tributaries (i.e., the Peace, Liard, and Slave Rivers) advanced by about 3 days decade ${ }^{-1}$. Burn (2008) examined the trend behaviour of nine measures of the timing of runoff for gauging stations within the Liard, Peace, and Athabasca River basins over various periods during the late 20th century. They found field significant trends (i.e., a collection of time series for a hydrologic variable that exhibits a greater number of trends than expected by chance) in several of the variables analyzed, and in particular they observed strong shifts in timing towards earlier spring freshet for all periods, especially in headwater catchments. Similar results were obtained in the prairies (Burn et al., 2008) and the Rocky Mountain eastern slopes (Rood et al., 2008). These trends are consistent with increasing spring air temperatures and an earlier occurrence of snowmelt reported across the domain (Sects. 2 and 4).

The timing of low flows has also received attention (Ehsanzadeh and Adamowski, 2007, 2010; Khaliq et al., 2008; Burn et al., 2010). Annual low flow events of various durations have generally been observed to show a decreasing (i.e., arriving later) trend in southwestern Canada and an increasing trend in the northwest (Khaliq et al., 2008). In the prairie region, Burn et al. (2008) found a decreasing trend in the timing of summer rainfall-driven peak flow events, while over a broader part of western Canada, Cunderlik and Ouarda (2009) found no significant trends in the timing of fall rainfall-dominated high flow events.

Given the limited record length for flow analyses, the potential for computed trends to be influenced by shorter-term variability and large-scale modes of oceanic-atmospheric circulation variability is high. Woo et al. (2006) discuss this issue and illustrate the difficulty in attributing trends detected in short records to long-term climate change. Some studies have accounted for modes of large-scale variability to examine the trends in the absence of their influence. For example, St. Jacques et al. (2010) removed the signal due to the PDO in flows at a number of stations across the southern Canadian Rockies and southern Alberta, and they found that observed and naturalized flows still exhibited predominantly decreasing trends since as far back as the early 20th century. Burn's (2008) analysis of flow timing indices in the Mackenzie River basin examined the relationship with meteorological variables and six large-scale circulation indices. They concluded that although several of the timing measures are related to large-scale circulation patterns, there is a relationship with increasing spring air temperatures, and the large-scale periodic influences are not a dominant contributor to the observed trends. Bonsal and Shabbar (2008) re- view the past Canadian research on the impacts of largescale circulation patterns on low flows and report a higher frequency of low flow events in western Canada associated with the warmer and drier conditions during El Niño events and positive phases of the PDO and the Pacific/North American (PNA) pattern. They also note that the spatial and temporal aspects of the relationships between low flows and these climatic patterns are strongly influenced by local hydroclimatic complexities, particularly in the mountainous watersheds.

\section{Discussion and conclusions}

\subsection{Data set quality and length}

The observational data sets described throughout this paper provide the best available long-term, quality-controlled products for examining Earth system change and variability in western Canada. Considerable effort has gone into ensuring their reliability for trend detection and their intercomparability for regional assessments, including corrections for known sources of inhomogeneity, station relocation, measurement error, and data gaps. The data are, however, subject to several notable limitations. First, the hydro-climatic observational network is sparse in northern Canada and regional assessments require extrapolation and interpolation over vast areas. This is likely less problematic for air temperature than for precipitation, for example, which can exhibit greater local variability and is more sensitive to the density of the observing network and methods for adjusting systematic measurement errors (Rapaić et al., 2015). Rapaić et al. (2015) noted that considerable care is needed when using gridded climate data sets in local or regional-scale applications in data sparse regions such as the Canadian Arctic, where, for example, they found that the adjustments used in the CANGRD product led to a doubling of precipitation trend magnitude compared to a multi-data set average. Sparseness of the observing network is also an issue in mountainous areas, where there are relatively few long-term sites at high elevations - a problem that exists globally (Adam et al., 2006). Monitoring in cold, harsh conditions and the associated measurement error also present a challenge; in particular, solid precipitation measurements are highly susceptible to error as a result of wind and turbulence around the gauge and require careful correction (Yang et al., 2005).

Another issue involves the record length of these observational data sets. The longest climate station records go back to the early 20th century or late 19th century for a few select sites, while across much of the northern parts of western Canada, there are very few climate records going back much further than about 1950. This is also a problem for other variables, such as snow and freshwater ice cover, and particularly river discharge. As noted previously, it is difficult to discern long-term trends from periodic effects in short records, 
and the results may be highly sensitive to analysis period. Large-scale oceanic-atmospheric circulation patterns, such as ENSO and PDO, are known to influence the variability of cryospheric and hydrological systems on timescales of years to decades (Whitfield et al., 2010) and can thus significantly complicate the detection and attribution of trends (Woo et al., 2006). In many instances, the closure of stations or the automation of measurement procedures has caused gaps or inconsistencies in the data, also limiting the length of observational data sets. Since about the mid-1990s there has been a considerable reduction in active climate, snow, and discharge monitoring stations across this region, which restricts the analyses of long-term change.

\subsection{Climatic, cryospheric, and hydrological change}

Despite the data limitations noted, observations have shown clear and systematic patterns of change in climatic regime and cryospheric response over western Canada. The various lines of evidence are consistent and mutually supportive. Warming has been pervasive, especially during winter and spring and at higher latitudes (warming rates in western Canada are among the highest globally), while changes in precipitation have been more varied, both regionally and seasonally. Widespread decreases in winter precipitation in much of southwestern Canada have been observed, and a decline in the fraction of precipitation falling as snow is very likely associated with rising winter/spring temperatures and a shift in the timing of the $0^{\circ} \mathrm{C}$ isotherm. The snow to rain transition is sensitive to increasing temperature, particularly when and where precipitation occurs at temperatures near $0^{\circ} \mathrm{C}$ (Rasouli et al., 2015). These changes are also driving widespread reductions in snow depth, snow cover extent and duration, and freshwater ice cover, primarily in spring as opposed to fall. This has led to an earlier occurrence of the spring freshet across the region. Warmer air temperatures are associated with rising permafrost temperatures, thawing and degradation of permafrost, and increasing glacier melt. Recent declines in winter and annual glacier mass balance at several sites have been attributed to reduced snow accumulation in association with a shift in the PDO in 1976 (Demuth and Keller, 2006; Moore et al., 2009), but they may also be due in part to a shift in precipitation phase from snow to rain. Conditions observed in the winter and spring of 2015 across the southern Canadian Rocky Mountains may be indicative of what the future holds under an increasingly warmer climate. Anomalously warm conditions led to reduced snowpacks and early disappearance of snow cover (despite nearnormal winter precipitation along the central ranges), also leading to end-of-summer snow lines retreating off the tops of most glaciers and record net negative glacier mass balance for the period of available measurements (Demuth and Ednie, 2016).

In general, river discharge magnitude has not shown longterm and regionally coherent trends, other than increasing winter flows in the north. This may partly reflect aspects of periodicity and the influence of large-scale modes of climate variability over interannual to inter-decadal scales (e.g., ENSO, PDO). However, it has been found that these modes are not the sole driver of observed trends in other variables (Vincent et al., 2015). The mixed responses in discharge magnitude are probably the result of interactions between multiple processes and drivers - which may be confounding and multi-directional - across various temporal and spatial scales and geographic locations.

\subsection{Insights on change from the WECC observatories}

While in most cases, the length of record at the CCRN WECC observatories (Fig. 1) precludes robust time series analysis as conducted on the national climatological and hydrometric data sets, the observatories provide critical platforms to understand hydrological responses and process interactions and to diagnose how changes are manifested at scales where field-based scientific investigations are undertaken.

One of the most notable changes in the cryosphere is the widespread thaw of permafrost across the circumpolar region (Hinzman et al., 2005; Schuur et al., 2015). In the Mackenzie and Yukon River basins of North America, recent changes in winter low flows have been ascribed to permafrost thaw and adjusting pathways (Walvoord and Striegl, 2007; St. Jacques and Sauchyn, 2009). In contrast, at the headwater and mesoscales $\left(<1000 \mathrm{~km}^{2}\right)$, these trends are rarely observed, creating some uncertainty as to whether activation of new and deeper subsurface flow pathways is the cause of change at larger scales. Other factors such as increased rainfall (Spence and Rausch, 2005), changing seasonality of precipitation (Whitfield et al., 2004), changing landscape connectivity (Connon et al., 2014), and over-winter thaw events and changing surface water storage and runoff pathways (Spence et al., 2014) act to alter streamflow volume independently of widespread permafrost thaw.

Several WECC observatories have been operational since the 1990s in permafrost-underlain catchments and have undergone change associated with warming. The most dramatic change has been observed at Scotty Creek in the Taiga Plains near Fort Simpson, NT, where degradation in permafrost has resulted in decreasing and fragmented forest cover (Baltzer et al., 2014) and increasing wetland coverage and connectivity and drainage efficiency (Quinton et al., 2011; Connon et al., 2014). From 1947 to 2008, permafrost coverage declined at the site from 70 to $43 \%$ (Chasmer et al., 2010) and wetland permafrost-free areas expanded and coalesced. Connon et al. (2014) showed that increases in flows observed in the region were not a result of reactivation of subsurface flow pathways from permafrost thaw but from an increased connectivity of surface pathways and, to a lesser extent, from increases in overall precipitation. Bogs that were formerly 
isolated on the landscape became incorporated into the basin drainage network, increasing runoff efficiency through time.

Further north at the Baker Creek, NT, WECC observatory, changing precipitation regimes from warmer temperatures are more strongly influencing the hydrological response of this watershed. Here, the Precambrian Shield geological setting, abundant lakes, and thin glacial-fluvial soils are not particularly sensitive to changes in thermal regime, but changes in lake storage can rapidly change the runoff contributing area available for river discharge formation. The WECC observatory has a distinct threshold-response runoff regime (Spence, 2006) where increasingly large areas of the watershed connect and can contribute to runoff as lake storage increases (Phillips et al., 2011). Spence et al. (2011) have documented sudden changes in streamflow regimes as the climate has changed. Previously, peak flows were observed during spring freshet in response to the relatively rapid snowmelt, whereas in more recent years, large summer and fall precipitation events that are rare in the historical record have resulted in enhanced late-season flows. In addition, Spence et al. (2015) revealed the emergence of new streamflow regimes as a result of late-season rains, with enhanced winter storage and streamflow being characteristic of a transition from a nival toward a pluvial regime, and they showed how this influences the biogeochemical system.

Other WECC observatories underlain with permafrost (notably Wolf Creek, YT, and Trail Valley Creek, NT) have undergone less dramatic changes since the 1990s despite warming air temperatures, although important insights to potential response from change are emerging. In Trail Valley Creek where permafrost is continuous, active layers have increased and there have been gradual expansions of taller shrub vegetation (Lantz et al., 2012). Shi et al. (2015) examined several timing metrics of the runoff hydrograph and revealed complex responses for 27 years of data. Unlike what has been reported in southern latitudes (Berghuijs et al., 2014), a decline in total winter snow accumulation had only minor influence on the timing of springtime streamflow. Offsetting effects of springtime temperature fluctuations and winter warming resulted in small changes to the freshet hydrograph, whereas delayed springtime rain had a more notable impact on the late-summer flow regimes. Overall, despite major changes in climate, vegetation, and active layer thickness, changes to streamflow were limited. At Wolf Creek, an alpine watershed underlain with discontinuous permafrost, recent changes in shrub abundance at higher elevation has resulted in some changes in accumulation of snow (Pomeroy et al., 2006), yet responses in the streamflow hydrograph to change have yet to be realized with 18 years of data. Using a hydrological model to simulate future climates, Rasouli et al. (2014) showed that while the hydrological impacts of climate warming are unequivocal (i.e., reduced snow contributions to streamflow, shorter snow-covered period, greater evapotranspiration), the magnitude and direction of the impact of warming on stream- flow depends more on changes to future precipitation than on future warming.

In more southerly locations, the influence of land use and climate change combined to dramatically alter hydrological regimes in Smith Creek, MB, an agricultural basin characteristic of the southeastern prairies. Warming temperatures, increased rainfall fraction, earlier melt, and more multipleday rainfall events have, in concert with extensive wetland drainage and increase in basin hydraulic connectivity, resulted in an overall dramatic increase in flows generated from snowmelt, rain-on-snowmelt, and rainfall runoff processes, with the greatest increases for rainfall runoff and a relative decline in the proportion of streamflow derived from snowmelt from over $85 \%$ in the 20th century to less than $50 \%$ in the last 5 years (Dumanski et al., 2015). Conversely, in the eastern slopes of the Rocky Mountains, Marmot Creek, $\mathrm{AB}$, has shown considerable resilience in its flow regime. Despite winter warming, declining low-elevation snowpacks, forest cover reduction, and, more recently, extreme weather, streamflow volume, timing, and magnitude of peak have not changed since 1962 (Harder et al., 2015). An increase in the fraction of precipitation occurring in spring and the frequency of multiple-day rainfall events may have counteracted warmer conditions and lower snowpacks at low elevations. Substantial sub-surface storage in the basin may further buffer the impacts of climate variability. The devastating flood of 2013 that affected Calgary and much of the eastern slopes was in fact buffered by processes operating within headwater catchments as flow responses were less than anticipated based on precipitation statistics. Of particular interest is that 2 years later in 2015, despite relatively normal total volumes of winter precipitation, smaller snowpacks (due to more mid-winter rainfall and melt events) have resulted in dramatically lower streamflows and record low groundwater levels, exacerbating the ecological and societal impact of drought conditions that arrived in the spring.

Ongoing research at the WECC observatories will continue to address the interplay among changes in climate, cryosphere, ecology, and the hydrological responses observed, and place larger-scale patterns in a local context. There are a number of outstanding research questions that remain to be addressed and will be a focus of ongoing research: (1) the role of changing vegetation and ecological assemblages (including land-use change) on hydrology at the WECC observatories; (2) the importance of fall and overwinter hydrological processes, which are often neglected in field-based research yet are increasingly being identified as important when evaluating change; (3) the influence of thawing permafrost and a reduction in seasonally frozen ground on hydrological response across a gradient of watersheds in different thermal and physiographic environments; and (4) how the decline in snow (in terms of volume, duration, and as a fraction of total precipitation) will influence all aspects of the hydrological cycle. An important activity of CCRN will be to develop conceptual and numerical models 
of change for each WECC observatory using future climate scenarios and a common experimental framework linking all biophysical aspects of these systems. While large national observation networks are critical for baseline assessment of change, linking this to research at small scales is still required to interpret patterns observed in larger basins and will be a focus of the network.

\subsection{Concluding remarks}

To conclude we note that rapid warming is occurring throughout the interior of western Canada, as in other cold region environments globally, with profound implications in terms of landscape and hydrological and change. However, hydrological responses are complex and spatially variable, reflecting multiple process interactions at sub-basin scale that vary across the region, and depend strongly on changes in precipitation form and timing. There has been much speculation on the future trajectory of hydrological change in cold regions in relation to climate projections, but this has not often been grounded on appropriate conceptual understanding and process-based representation of the underlying response mechanisms. Given the complexities involved, this is required to develop plausible scenarios of change for the 21st century, especially considering that while certain processes and their interaction are inherently accounted for in some physically based models, other factors are likely not (e.g., land cover changes such as deglaciation, permafrost degradation, changing vegetation and ecological assemblages, and their influence on hydrology). Simple projections of change are therefore likely to be misleading. There is clearly a need to diagnose and better understand the causes and mechanisms underlying the observed pattern in flow regime and its variability over the region if projections of future change (and associated societal impacts) are to be made with any confidence.

\section{Data availability}

All data sets used here are publicly available and can be accessed through the links and references we have provided.

Acknowledgements. We gratefully acknowledge the Natural Sciences and Engineering Research Council of Canada (NSERC) for funding the CCRN through their Climate Change and Atmospheric Research (CCAR) Initiative. We also thank Kevin Shook and Ross Brown for their contributions in trend analysis of the hydrometric and snow cover data, Mike Demuth for providing updated Peyto Glacier mass balance data, and John Pomeroy for help with editing the manuscript. Two anonymous reviewers provided comments that were greatly beneficial and constructive, and we thank them for this.

Edited by: B. Schaefli

\section{References}

Abdul Aziz, O. I. and Burn, D. H.: Trends and variability in the hydrological regime of the Mackenzie River Basin, J. Hydrol., 319, 282-294, 2006.

ACIA (Arctic Climate Impacts Assessment): Impacts of a Warming Arctic: Arctic Climate Impact Assessment, Cambridge University Press, ISBN 0521617782, 139 pp., 2004.

Adam, J. C., Clark, E. A., Lettenmaier, D. A., and Wood, E. F.: Correction of global precipitation products for orographic effects, J. Climate, 19, 15-38, 2006.

Adam, J. C., Hamlet, A. F., and Lettenmaier, D. P.: Implications of global climate change for snowmelt hydrology in the twenty-first century, Hydrol. Process., 23, 962-972, 2009.

AMAP (Arctic Monitoring and Assessment Programme): Arctic Climate Issues 2011: Changes in Arctic Snow, Water, Ice and Permafrost, SWIPA 2011 Overview Report, ISBN 978-82-7971073-8, 97 pp., 2012.

Baltzer, J. L., Veness, T., Chasmer, L. E., Sniderhan, A. E., and Quinton, W. L.: Forests on thawing permafrost: fragmentation, edge effects, and net forest loss, Global Change Biol., 20, 824834, 2014.

Bao, Z., Kelly, R., and Wu, R.: Variability of regional snow cover in spring over western Canada and its relationship to temperature and circulation anomalies, Int. J. Climatol., 31, 1280-1294, 2011.

Bash, E. A. and Marshall, S .J.: Estimation of glacial melt contributions to the Bow River, Alberta, Canada, using a radiationtemperature melt model, Ann. Glaciol., 55, 138-152, 2014.

Beedle, M. J., Menounos, B., and Wheate, R.: Glacier change in the Cariboo Mountains, British Columbia, Canada (1952-2005), The Cryosphere, 9, 65-80, doi:10.5194/tc-9-65-2015, 2015.

Beilman, D. W. and Robinson, S. D.: Peatland permafrost thaw and landform type along a climate gradient, in: Proceedings of the 8th International Conference on Permafrost, Zurich, Switzerland, 21-25 July 2003, edited by: Phillips, M., Springman, S. M., and Arenson, L. U., Swets \& Zeitlinger, Lisse, Netherlands. Vol. 1, 61-65, 2003.

Beltaos, S.: Threshold between mechanical and thermal breakup of river ice cover, Cold Reg. Sci. Technol., 37, 1-13, 2003.

Beltaos, S. and Burrell, B. C.: Climatic change and river ice breakup, Can. J. Civil Eng., 30, 145-155, 2003.

Beltaos, S. and Prowse, T. D.: River-ice hydrology in a shrinking cryosphere, Hydrol. Process., 23, 122-144, 2009.

Berghuijs, W. R., Woods, R. A., and Hrachowitz, M.: A precipitation shift from snow towards rain leads to a decrease in streamflow, Nat. Clim. Change, 4, 583-586, 2014.

Bolch, T., Menounos, B., and Wheate, R.: Landsat-based inventory of glaciers in western Canada, 1985-2005, Remote Sens. Environ., 114, 127-137, 2010.

Bonsal, B. R. and Prowse, T. D.: Trends and variability in spring and autumn $0{ }^{\circ} \mathrm{C}$-isotherm dates over Canada, Climatic Change, 57, 341-358, 2003.

Bonsal, B. R. and Regier, M.: Historical comparison of the 2001/2002 drought in the Canadian Prairies, Clim. Res., 33, 229242, 2007.

Bonsal, B. R. and Shabbar, A.: Impacts of large-scale circulation variability on low streamflows over Canada: A review, Can. Water Resour. J., 33, 137-154, 2008. 
Bonsal, B. R., Zhang, X., Vincent, L. A., and Hogg, W.D.: Characteristics of daily and extreme temperatures over Canada, J. Climate, 14, 1959-1976, 2001a.

Bonsal, B. R., Shabbar, A., and Higuchi, K.: Impacts of low frequency variability modes on Canadian winter temperature, Int. J. Climatol., 21, 95-108, 2001b.

Bonsal, B. R., Wheaton, E. E., Chipanshi, A. C., Lin, C., Sauchyn, D. J., and Wen, L.: Drought research in Canada: A review, Atmos.-Ocean, 49, 303-319, 2011.

Bonsal, B. R., Aider, R., Gachon, P., and Lapp, S.: An assessment of Canadian prairie drought: past, present, and future, Clim. Dynam., 41, 501-516, 2013.

Brasnett, B.: A global analysis of snow depth for numerical weather prediction, J. Appl. Meteorol., 38, 726-740, 1999.

Bring, A., Fedorova, I., Dibike, Y., Hinzman, L., Mård, J., Mernild, S. H., Prowse, T., Semenova, O., Stuefer, S. L., and Woo, M.-K.: Arctic terrestrial hydrology: A synthesis of processes, regional effects, and research challenges, J. Geophys. Res. Biogeosci., 121, 621-649, doi:10.1002/2015JG003131, 2016.

Brown, R. D. and Braaten, R. O.: Spatial and temporal variability of Canadian monthly snow depths, 1946-1995, Atmos.-Ocean, 36, 37-54, 1998.

Brown, J., Ferrians Jr., O. J., Heginbottom, J. A., and Melnikov., E. S.: Circum-arctic map of permafrost and ground ice conditions, Boulder, Colorado, National Snow and Ice Data Center, Digital media, available at: https://nsidc.org/data/ggd318, 2001.

Brown, R. D., Derksen, C., and Wang, L.: A multi-data set analysis of variability and change in Arctic spring snow cover extent, 1967-2008, J. Geophys. Res., 115, D16111, doi:10.1029/2010JD013975, 2010.

Burgess, M. M. and Smith, S. L.: 17 years of thaw penetration and surface settlement observations in permafrost terrain along the Norman Wells pipeline, Northwest Territories, Canada, in: Proceedings of the 8th International Conference on Permafrost, Zurich, Switzerland, 21-25 July, 2003, edited by: Phillips, M., Springman, S. M., and Arenson, L. U., Swets \& Zeitlinger, Lisse, Netherlands, 107-112, 2003.

Burn, C. R.: The response (1958-1997) of permafrost and nearsurface ground temperatures to forest fire, Takhini River valley, southern Yukon Territory, Can. J. Earth Sci., 35, 184-199, 1998.

Burn, C. R.: Permafrost Distribution and Stability. In: Changing Cold Environments: A Canadian Perspective, edited by: French, H., and Slaymaker, O., John Wiley and Sons Ltd., 126-146, 2012

Burn, C. R. and Kokelj, S. V.: The environment and permafrost of the Mackenzie Delta area, Permafrost Periglac., 20, 83-105, 2009.

Burn, C. R. and Zhang, Y.: Sensitivity of active layer development of winter conditions north of treeline, Mackenzie delta area, western arctic coast, in: Proceedings of the 6th Canadian Permafrost Conference, Calgary, Alberta, 12-16 September 2010, Canadian Geotechnical Society, Burnaby, BC, 1458-1465, 2010.

Burn, C. R., Mackay, J. R., and Kokelj, S. V.: The thermal regime of permafrost and its susceptibility to degradation in upland terrain near Inuvik, N.W.T., Permafrost Periglac., 20, 221-227, 2009.

Burn, D. H.: Climatic influences on streamflow timing in the headwaters of the Mackenzie River Basin, J. Hydrol., 352, 225-238, 2008.
Burn, D. H. and Hag Elnur, M. A.: Detection of hydrologic trends and variability, J. Hydrol., 255, 107-122, 2002.

Burn, D. H., Cunderlik, J. M., and Pietroniro, A.: Hydrological trends and variability in the Liard River basin, Hydrolog. Sci. J., 49, 53-67, 2004a.

Burn, D. H., Abdul Aziz, O. I., and Pietroniro, A.: A comparison of trends in hydrological variables for two watersheds in the Mackenzie River Basin, Can. Water Resour. J., 29, 283-298, 2004b.

Burn, D. H., Fan, L., and Bell, G.: Identification and quantification of streamflow trends on the Canadian Prairies. Hydrol. Sci. J., 53, 538-549, 2008.

Burn, D. H., Sharif, M., and Zhang, K.: Detection of trends in hydrological extremes for Canadian watersheds, Hydrol. Process. 24, 1781-1790, 2010.

Bush, E. J., Loder, J. W., James, T. S., Mortsch, L. D., and Cohen, S. J.: An overview of Canada's changing climate, in: Canada in a Changing Climate: Sector Perspectives on Impacts and Adaptation, edited by: Warren, F. J. and Lemmen, D. S., Government of Canada, Ottawa, Ontario, 23-64, 2014.

Callaghan, T. V., Johansson, M., Brown, R. D., Groisman, P. Y., Labba, N., Radionov, V., Barry, R. G., Bulygina, O. N., Essery, R. L. H., Frolov, D. M., Golubev, V. N., Grenfell, T. C., Petrushina, M. N., Razuvaev, V. N., Robinson, D. A., Romanov, P., Shindell, D., Shmakin, A. B., Sokratov, S. A., Warren, S., and Yang, D.: The changing face of Arctic snow cover: A synthesis of observed and projected changes, Ambio, 40, 17-31, 2011a.

Callaghan, T. V., Johansson, M., Brown, R. D., Groisman, P. Y., Labba, N., Radionov, V., Bradley, R. S., Blangy, S., Bulygina, O. N., Christensen, T. R., Colman, J. E., Essery, R. L. H., Forbes, B. C., Forchhammer, M. C., Golubev, V. N., Honrath, R. E., Juday, G. P., Meshcherskaya, A. V., Phoenix, G. K., Pomeroy, J., Rautio, A., Robinson, D. A., Schmidt, N. M., Serreze, M. C., Shevchenko, V. P., Shiklomanov, A. I., Shmakin, A .B., Sköld, P., Sturm, M., Woo, M.-K., and Wood, E. F.: Multiple effects of changes in Arctic snow cover, Ambio, 40, 32-45, 2011 b.

Carey, S. K., Tetzlaff, D., Seibert, J., Soulsby, C., Buttle, J., Laudon, H., McDonnell, J., McGuire, K., Caissie, D., Shanley, J., Kennedy, M., Devito, K., Pomeroy, J. W.: Inter-comparison of hydro-climatic regimes across northern catchments: synchronicity, resistance and resilience, Hydrol. Process., 24, 3591-3602, 2010.

Chasmer, L., Hopkinson, C., and Quinton, W. L.: Quantifying errors in discontinuous permafrost plateau change from optical data, Northwest Territories, Canada: 1947-2008, Can. J. Remote Sensing, 36, S211-S223, 2010.

Chen, J., and Ohmura, A.: Estimation of alpine glacier water resources and their change since the 1970s, in: Hydrology of Mountainous Regions: I - Hydrological Measurements; the Water Cycle, Proceedings of two Lausanne Symposia, August 1990, IAHS Publication No. 193, 127-135, 1990.

Comeau, L. E., Pietroniro, A., and Demuth, M. N.: Glacier contribution to the North and South Saskatchewan Rivers, Hydrol. Process., 23, 2640-2653, 2009.

Connon, R. F., Quinton, W. L., Craig, J. R., and Hayashi, M.: Changing hydrologic connectivity due to permafrost thaw in the lower Liard River valley, NWT, Canada, Hydrol. Process., 28, 4163-4178, 2014. 
Cunderlik, J. M. and Ouarda, T. B. M. J.: Trends in the timing and magnitude of floods in Canada, J. Hydrol., 375, 471-480, 2009.

DeBeer, C. M. and Sharp, M. J.: Recent changes in glacier area and volume within the southern Canadian Cordillera, Ann. Glaciol., 46, 215-221, 2007.

DeBeer, C. M., Wheater, H. S., Quinton, W., Carey, S. K., Stewart, R., MacKay, M., and Marsh, P.: The changing cold regions network: Observation, diagnosis, and prediction of environmental change in the Saskatchewan and Mackenzie River basins, Canada, Sci. China-Earth Sci., 58, 46-60, 2015.

de Rham, L. P., Prowse, T. D., and Bonsal, B.: Temporal variations in river-ice break-up over the Mackenzie River Basin, Canada, J. Hydrol., 349, 441-454, 2008.

Demuth, M. N., and Ednie, M.: A glacier condition and thresholding rubric for use in assessing protected area/ecosystem functioning, Geological Survey of Canada, open file 8031, 53 pp., doi:10.4095/297892, 2016.

Demuth, M. N. and Keller, R.: An assessment of the mass balance of Peyto Glacier (1966-1995) and its relation to recent and pastcentury climatic variability, in: Peyto Glacier: One Century of Science, edited by: Demuth, M. N., Munro, D. S., and Young, G. J., National Hydrology Research Institute Science Report No. 8, 83-132, 2006.

Demuth, M. N. and Pietroniro A.: The Impact of Climate Change on the Glaciers of the Canadian Rocky Mountain Eastern Slopes and Implications for Water Resource-related Adaptation in the Canadian Prairies, "Phase 1" - Headwaters of the North Saskatchewan River Basin, Report to the Climate Change Action Fund-Prairie Adaptation Research Collaborative (PARC) Project P55, Geological Survey of Canada Open File 4322, 162 pp. and technical appendices, 2003.

Demuth, M. N., Pinard, V., Pietroniro, A., Luckman, B. H., Hopkinson, C., Dornes, P., and Comeau, L.: Recent and Past-century Variations in the Glacier Resources of the Canadian Rocky Mountains - Nelson River System, Terra Glacialis Special Issue - Mountain Glaciers and Climate Changes of the Last Century, 27-52, 2008.

Demuth, M. N., Wilson, P., and Haggarty, D.: Glaciers of the Ragged Range, Nahanni National Park Reserve, Northwest Territories, Canada, in: Global Land Ice Measurements from Space, edited by: Kargel, J., Leonard, G. J., Bishop, M. P., Kääb, A., and Raup, B., Springer-Praxis Books, 375-383, 2014.

Derksen, C. and Brown, R.: Spring snow cover extent reductions in the 2008-2012 period exceeding climate model projections, Geophys. Res. Lett., L19504, 39, doi:10.1029/2012GL053387, 2012.

Derksen, C., Walker, A., LeDrew, E., and Goodison, B.: Time-series analysis of passive-microwave-derived central North American snow water equivalent imagery, Ann. Glaciol., 34, 1-7, 2002.

Derksen, C., Walker, A., and Goodison, B.: A comparison of 18 winter seasons of in situ and passive microwave-derived snow water equivalent estimates in Western Canada, Remote Sens. Environ., 88, 271-282, 2003.

Derksen, C., Brown, R., and Walker, A.: Merging conventional (1915-92) and passive microwave (1978-2002) estimates of snow extent and water equivalent over Central North America, J. Hydrometeorol., 5, 850-861, 2004.

Derksen, C., Brown, R., and MacKay, M.: Mackenzie Basin snow cover: Variability and trends from conventional data, satellite remote sensing, and Canadian regional climate model simulations, in: Cold Region Atmospheric and Hydrologic Studies, The Mackenzie GEWEX Experience, Volume 1: Atmospheric Dynamics, edited by: Woo, M.-K., Springer, Berlin Heidelberg, 213-239, 2008.

Derksen, C., Smith, S. L., Sharp, M., Brown, L., Howell, S., Copland, L., Mueller, D. R., Gauthier, Y., Fletcher, C. G., Tivy, A., Bernier, M., Bourgeois, J., Brown, R., Burn, C. R., Duguay, C., Kushner, P., Langlois, A., Lewkowicz, A. G., Royer, A., and Walker, A.: Variability and change in the Canadian cryosphere, Clim. Change, 115, 59-88, 2012.

Déry, S. J. and Brown, R. D.: Recent northern hemisphere snow cover extent trends and implications for the snow-albedo feedback, Geophys. Res. Lett., 34, L22504, doi:10.1029/2007GL031474, 2007.

Déry, S. J. and Wood, E. F.: Decreasing river discharge in northern Canada, Geophys. Res. Lett., 32, L10401, doi:10.1029/2005GL022845, 2005.

Déry, S. J., Mlynowski, T. J., Hernández-Henríquez, M. A., and Straneo, F.: Interannual variability and interdecadal trends in Hudson Bay streamflow, J. Marine. Syst., 88, 341-351, 2011.

Duguay, C. R., Prowse, T. D., Bonsal, B. R., Brown, R. D., Lacrooix, M. P., and Ménard, P.: Recent trends in Canadian lake ice cover, Hydrol. Process., 20, 781-801, 2006.

Dumanski, S., Pomeroy, J. W., and Westbrook, C. J.: Hydrological regime changes in a Canadian Prairie basin, Hydrol. Process., 29, 3893-3904, doi:10.1002/hyp.10567, 2015.

Dyer, J. L. and Mote, T. L.: Spatial variability and trends in observed snow depth over North America, Geophys. Res. Lett., 33, L16503, doi:10.1029/2006GL027258, 2006.

Dyer, J. L. and Mote, T. L.: Trends in snow ablation over North America, Int. J. Climatol., 748, 739-748, 2007.

Ehsanzadeh, E. and Adamowski, K.: Detection of trends in low flows across Canada, Can. Water Resour. J., 32, 251-264, 2007.

Ehsanzadeh, E. and Adamowski, K.: Trends in timing of low stream flows in Canada: impact of autocorrelation and long-term persistence, Hydrol. Process., 24, 970-980, 2010.

Environment Canada: Climatology of Temperature and Precipitation, https://weather.gc.ca/saisons/clim_e.html, last access: March 2016.

Frei, A. and Robinson, D. A.: Northern hemisphere snow extent: Regional variability 1972-1994, Int. J. Climatol., 19, 15351560, 1999.

Frei, A., Tedesco, M., Lee, S., Foster, J., Hall, D. K., Kelly, R., and Robinson, D. A.: A review of global satellite-derived snow products, Adv. Space Res., 50, 1007-1029, 2012.

Gan, T. Y., Gobena, A. K., and Wang, Q.: Precipitation of southwestern Canada: Wavelet, scaling, multifractal analysis, and teleconnection to climate anomalies, J. Geophys. Res., 112, D10110, doi:10.1029/2006JD007157, 2007.

Ge, Y. and Gong, G.: North American snow depth and climate teleconnection patterns, J. Climate, 22, 217-233, 2009.

Goulding, H. L., Prowse, T. D., and Beltaos, S.: Spatial and temporal patterns of break-up and ice-jam flooding in the Mackenzie Delta, NWT, Hydrol. Process., 23, 2654-2670, 2009.

Gray, D. M. and Male, D. H. (Eds.): Handbook of Snow: Principles, Processes, Management \& Use, Pergamon Press, Toronto, ON, 776 pp., 1981. 
Hall, D. K., and Riggs, G. A.: Accuracy assessment of the MODIS snow products, Hydrol. Process., 21, 1534-1547, 2007.

Hall, D. K., Riggs, G. A., Salomonson, V. V., DiGirolamo, N. E., and Bayr, K. J.: MODIS snow-cover products, Remote Sens. Environ., 83, 181-194, 2002.

Hall, D. K., Kelly, R. E. J., Foster, J. L., and Chang, A. T. C.: Estimation of snow extent and snow properties, in: Encyclopedia of Hydrological Sciences, edited by: Anderson, M. G., and McDonnell, J. J., John Wiley \& Sons, doi:10.1002/0470848944.hsa062, 2006.

Hall, F. G.: Introduction to special section: BOREAS in 1999: Experiment and science overview, J. Geophys. Res.-Atmos., 104, 27627-27639, 1999.

Hanesiak, J. M., Stewart, R. E., Bonsal, B. R., and 36 others: Characterization and summary of the 1999-2005 Canadian prairie drought, Atmos.-Ocean, 49, 421-452, 2011.

Hansen, J., Ruedy, R., Sato, M., and Lo, K.: Global surface temperature change, Rev. Geophys., 48, RG4004, doi:10.1029/2010RG000345, 2010.

Harder, P., Pomeroy, J. W., and Westbrook, C. J.: Hydrological resilience of a Canadian Rockies Headwaters basin subject to changing climate, extreme weather and forest management, Hydrol. Process., 29, 3905-3924, doi:10.1002/hyp.10596, 2015.

Harvey, K. D., Pilon, P. J., and Yuzyk, T. R.: Canada's reference hydrometric basin network (RHBN), in: Partnerships in water resource management, paper presented at CWRA 51st Annual Conference, Canadian Water Resource Association, Halifax, Nova Scotia, 1999.

Hinzman, L. D., Bettez, N. D., Bolton, W. R., and 29 others: Evidence and implications of recent climate change in northern Alaska and other Arctic regions, Climatic Change, 72, 251-298, 2005.

Hopkinson, C. and Demuth, M. N.: Using airborne lidar to assess the influence of glacier downwasting on water resources in the Canadian Rocky Mountains, Can. J. Remote Sens., 32, 212-222, 2006.

Hopkinson, C. and Young, G. J.: The effect of glacier wastage on the flow of the Bow River at Banff Alberta, 1951-1993, Hydrol. Process., 12, 1745-1762, 1998.

IPCC (Intergovernmental Panel on Climate Change): Climate Change 2013: The Physical Science Basis, Contribution of Working Group I to the Fifth Assessment Report of the Intergovernmental Panel on Climate Change, edited by: Stocker, T. F., Qin, D., Plattner, G.-K., Tignor, M., Allen, S. K., Boschung, J., Nauels, A., Xia, Y., Bex, V., and Midgley, P. M., Cambridge University Press, Cambridge, United Kingdom and New York, NY, USA, 1535 pp., 2013.

IPA (International Permafrost Association): PA-IPY Thermal State of Permafrost (TSP) Snapshot Borehole Inventory, Boulder, Colorado USA, National Snow and Ice Data Center, available at: http://dx.doi.org/10.7265/N57D2S25 (last access: 26 August 2015), 2010.

James, M., Lewkowicz, A. G., Smith, S. L., and Miceli, C. M.: Multi-decadal degradation and persistence of permafrost in the Alaska Highway corridor, northwest Canada, Environ. Res. Lett., 8, 045013, doi:10.1088/1748-9326/8/4/045013, 2013.

Jiskoot, H., Curran, C. J., Tessler, D. L., and Shenton, L. R.: Changes in Clemenceau Icefield and Chaba Group glaciers, Canada, related to hypsometry, tributary detachment, length- slope and area-aspect relations, Ann. Glaciol., 50, 133-143, 2009.

Jorgenson, M. T., Shur, Y., and Osterkamp, T. E.: Thermokarst in Alaska, in: Proceedings of the Ninth International Conference on Permafrost, Fairbanks, AK, 29 June to 3 July 2008, edited by: Kane, D. L., and Hinkel, K. M., Institute of Northern Engineering, University of Alaska Fairbanks, Vol. 1, 869-876, 2008.

Jost, G., Moore, R. D., Menounos, B., and Wheate, R.: Quantifying the contribution of glacier runoff to streamflow in the upper Columbia River Basin, Canada, Hydrol. Earth Syst. Sci., 16, 849-860, doi:10.5194/hess-16-849-2012, 2012.

Kelly, R.: Remote sensing and Canadian snow climatology. In: Changing Cold Environments: A Canadian Perspective, edited by: French, H. and Slaymaker, O., John Wiley and Sons Ltd., 66-86, 2012.

Kendall, M. G.: Rank Correlation Methods, 4th edition, Charles Griffin, London, UK, 272 pp., 1975.

Khaliq, M. N., Ouarda, T. B. M. J., Gachon, P., and Sushama, L.: Temporal evolution of low-flow regimes in Canadian rivers, Water Resour. Res., 44, W08436, doi:10.1029/2007WR006132, 2008.

Koshida, G., Cohen, S., and Mortsch, L.: Climate and water availability indicators in Canada: Challenges and a way forward, Part I - Indicators, Can. Water Resour. J., 40, 133-145, 2015.

Lacroix, M. P., Prowse, T. D., Bonsal, B. R., Duguay, C. R., and Ménard, P.: River Ice Trends in Canada, in: Proceedings for Canadian Geophysical Union - Hydrology Section. Committee on River Ice Processes and the Environment, 13th Workshop on the Hydraulics of Ice Covered Rivers, Hanover, NH, 15-16 September 2005, CGU HS Committee on River Ice Processes and the Environment, Edmonton, AB, 41-54, 2005.

Lantz, T. C., Marsh, P., and Kokelj, S. V.: Recent shrub proliferation in the Mackenzie Delta uplands and microclimatic implications, Ecosystems, 16, 47-59, 2013.

Latifovic, R. and Pouliot, D.: Analysis of climate change impacts on lake ice phenology in Canada using the historical satellite data record, Remote Sens. Environ., 106, 492-507, 2007.

Lenormand F., Duguay, C. R., and Gauthier, R.: Development of a historical ice database for the study of climate change in Canada Hydrol. Process., 16, 3707-3722, 2002.

Luckman, B. H.: Landscape and climate change in the central Canadian Rockies during the 20th century, Can. Geogr., 42, 319-336, 1998.

Male, D. H.: The Seasonal Snowcover, in: Dynamics of Snow and Ice Masses, edited by: Colbeck, S. C., Academic Press, New York, NY, 305-395, 1980.

Mann, H. B.: Nonparametric tests against trend, Econometrica, 13, 245-259, 1945.

Marshall, S. J., White, E., Demuth, M. N., Bolch, T., Wheate, R., Menounos, B., Beedle, M., and Shea, J.: Glacier Water Resources on the Eastern Slopes of the Canadian Rocky Mountains, Can. Water Resour. J., 36, 109-134, 2011.

Martz, L. W., Bruneau, J. F., and Rolfe, J. T.: Climate Change and Water, South Saskatchewan River Basin Final Technical Report, University of Saskatchewan, 252 pp., 2007.

McCarthy, D. P. and Smith, D. J.: Historical glacier activity in the vicinity of Peter Lougheed Provincial Park, Canadian Rocky Mountains, Western Geography, 4, 94-109, 1994. 
McClelland, J. W., Déry, S. J., Peterson, B. J., Holmes, R. M., and Wood, E. F.: A pan-arctic evaluation of changes in river discharge during the latter half of the 20th century, Geophys. Res. Lett., 33, L06715, doi:10.1029/2006GL025753, 2006.

Mekis, E. and Vincent, L. A.: Changes in daily and extreme temperature and precipitation indices related to droughts in Canada, in: 17th Conference on Applied Climatology, Whistler, B.C., Canada, 2008.

Mekis, E. and Vincent, L. A.: An overview of the second generation adjusted daily precipitation dataset for trend analysis in Canada, Atmos.-Ocean, 49, 163-177, 2011.

Mekis, E., Vincent, L. A., Shephard, M. W., and Zhang, X.: Observed trends in severe weather conditions based on humidex, wind chill, and heavy rainfall events in Canada for 1953-2012, Atmos.-Ocean, 53, 383-397, 2015.

Millett, B., Johnson, W. C., and Guntenspergen, G.: Climate trends of the North American prairie pothole region 1906-2000, Clim. Change, 93, 243-267, 2009.

Moore, R. D., Fleming, S. W., Menounos, B., Wheate, R., Fountain, A., Stahl, K., Holm, K., and Jakob, M.: Glacier change in western North America: influences on hydrology, geomorphic hazards and water quality, Hydrol. Process., 23, 42-61, 2009.

Mortsch, L., Cohen, S., and Koshida, G.: Climate and water availability indicators in Canada: Challenges and a way forward. Part II - Historic trends, Can. Water Resour. J., 40, 146-159, 2015.

MRBB (Mackenzie River Basin Board): The Mackenzie River Basin Board's 2012 Issue Report - Oil sands development, hydroelectric development, and climate change in the Mackenzie River Basin, Mackenzie River Basin Board Secretariat, Yellowknife, NT, 10 pp., 2012.

MSC (Meteorological Service of Canada): Canadian snow data CDROM - Introduction and brief documentation, CRYSYS project, Climate Processes and Earth Observation Division, Meteorological Service of Canada, Environment Canada, Downsview, Ontario, 2000.

Naz, B. S., Frans, C. D., Clarke, G. K. C., Burns, P., and Lettenmaier, D. P.: Modeling the effect of glacier recession on streamflow response using a coupled glacio-hydrological model, Hydrol. Earth Syst. Sci., 18, 787-802, doi:10.5194/hess-18-7872014, 2014.

Nazemi, A. and Wheater, H. S.: On inclusion of water resource management in Earth system models - Part 1: Problem definition and representation of water demand, Hydrol. Earth Syst. Sci., 19, 33-61, doi:10.5194/hess-19-33-2015, 2015.

Oerlemans, J.: On the response of valley glaciers to climatic change, in: Glacier Fluctuations and Climatic Change, edited by: Oerlemans, J., Kluwer Academic Publishers, 353-371, 1989.

Ommanney, S. C. L.: The inventory of Canadian glaciers: procedures, techniques, progress and applications, in: World Glacier Inventory - Proceedings of the Riederalp Workshop, September 1978, IAHS Publication No. 126, 35-44, 1980.

Ommanney, S. C. L.: History of glacier investigations in Canada, in: Satellite Image Atlas of Glaciers of the World - Glaciers of North America - Glaciers of Canada, edited by: Williams, R. S. and Ferrigno, J. G., US Geological Survey Professional Paper 1386-J-1, J27-J82, 2002a.

Ommanney, S. C. L.: Mapping Canada's glaciers, in: Satellite Image Atlas of Glaciers of the World - Glaciers of North America - Glaciers of Canada, edited by: Williams, R. S. and Ferrigno,
J. G., US Geological Survey Professional Paper 1386-J-1, J183J110, 2002b.

Ommanney, S. C. L.: Glaciers of the Canadian Rockies, in: Satellite Image Atlas of Glaciers of the World - Glaciers of North America - Glaciers of Canada, edited by: Williams, R. S. and Ferrigno, J. G., US Geological Survey Professional Paper 1386-J-1, J199J289, 2002c.

Østrem, G.: History of scientific studies at Peyto Glacier, in: Peyto Glacier, One Century of Science, edited by: Demuth, M. N., Munro, D. S., and Young, G. J., National Hydrology Research Institute Science Report No. 8, 1-23, 2006.

Peters, D. L., Atkinson, D., Monk, W. A., Tenenbaum, D. E., and Baird, D. J.: A multi-scale hydroclimatic analysis of runoff generation in the Athabasca River, western Canada, Hydrol. Process., 27, 1915-1934, 2013.

Phillips, R. W., Spence, C., and Pomeroy, J. W.,: Connectivity and runoff dynamics in heterogeneous basins, Hydrol. Process., 25, 3061-3075, 2011.

Pomeroy, J. W., Bewley, D. S., Essery, R. L. H., Hedstrom, N. R., Link, T., Granger, R. J., Sicart, J. E., Ellis, C. R., and Janowicz, J. R.: Shrub tundra snowmelt, Hydrol. Process., 20, 923-941, 2006.

Pomeroy, J. W., Stewart, R. E., and Whitfield, P. H.: The 2013 flood event in the South Saskatchewan and Elk River basins: Causes, assessment and damages, Can. Wat. Res. J., doi:10.1080/07011784.2015.1089190, online first, 2015.

Prowse, T. D.: River-ice ecology, II: Biological aspects, J. Cold Reg. Eng., 15, 17-33, 2001.

Prowse, T.: Lake and River ice in Canada, in: Changing Cold Environments: A Canadian Perspective, 1st edition, edited by: French, H., and Slaymaker, O., John Wiley \& Sons, 163-181, 2012.

Prowse, T. D. and Beltaos, S.: Climatic control of river-ice hydrology: a review, Hydrol. Process., 16, 805-822, 2002.

Prowse, T. D. and Bonsal, B. R.: Historical trends in river-ice breakup: a review, Nord. Hydrol., 35, 281-293, 2004.

Prowse, T. D. and Culp, J. M.: Ice breakup: A neglected factor in river ecology, Can. J. Civil Eng., 30, 128-144, 2003.

Prowse, T. D., Bonsal, B. R., Dugay, C. R., and Lacroix, M. P.: River-ice break-up/freeze-up: a review of climatic drivers, historical trends and future predictions, Ann. Glaciol., 46, 443-451, 2007.

Prowse, T. D., Furgal, C., Bonsal, B., and Edwards, T. W. D.: Climatic conditions in northern Canada: past and future, Ambio, 38, 257-265, 2009a.

Prowse, T. D., Furgal, C., Melling, H., and Smith, S. L.: Implications of climate change for northern Canada: the physical environment, Ambio, 38, 266-271, 2009b.

Prowse, T. D, Alfredsen, K., Beltaos, S., Bonsal, B., Duguay, C., Korhola, A., McNamara, J., Pienitz R., Vincent, W. F., Vuglinsky, V. and Weyhenmeyer, G. A.: Past and future changes in Arctic lake and river ice. Ambio, 40, 53-62m, 2011a.

Prowse, T., Alfredsen, K., Beltaos, S., Bonsal, B., Duguay, C., Korhola, A., McNamara, J., Vincent, W. F., Vuglinsky, V., and Weyhenmeyer, G. A.: Arctic freshwater ice and its climatic role, Ambio, 40, 46-52, $2011 \mathrm{~b}$.

Qian, B., Zhang, X., Chen, K., Feng, Y., and O'Brien, T.: Observed long-term trends for agroclimatic conditions in Canada, J. Appl. Meteorol. Clim., 49, 604-618, 2010. 
Quinton, W. L., Hayashi, M., and Chasmer, L. E.: Permafrost-thawinduced land-cover change in the Canadian subarctic: implications for water resources, Hydrol. Process., 25, 152-158, 2011.

Radić, V. and Hock, R.: Glaciers in the Earth's hydrological cycle: Assessments of glacier mass and runoff changes on global and regional scales, in: The Earth's Hydrological Cycle, edited by: Bengtsson, L., Bonnet, R.-M., Calisto, M., Destouni, G., Gurney, R., Johannessen, J., Kerr, Y., Lahoz, W. A., and Rast, M., Space Sciences Series of ISSI, 46, 813-837, 2014.

Rapić, M., Brown, R., Markovic, M., and Chaumont, D: An evaluation of temperature and precipitation surface-based and reanalysis datasets for the Canadian Arctic, 1950-2010, Atmos.-Ocean, 53, 283-303, 2015.

Rasouli, K., Pomeroy, J. W., Janowicz, J. R., Carey, S. K., and Williams, T. J.: Hydrological sensitivity of a northern mountain basin to climate change, Hydrol. Process., 28, 4191-4208, 2014.

Rasouli, K., Pomeroy, J. W., and Marks, D. G.: Snowpack sensitivity to perturbed climate in a cool mid-latitude mountain catchment, Hydrol. Process., 29, 3925-3940, 2015.

Razavi, S., Elshorbagy, A., Wheater, H., and Sauchyn, D.: Towards understanding nonstationarity in climate and hydrology through tree-ring proxy records, Water Resour. Res., 51, 18131830, 2015.

RIFWP (Rosenberg International Forum on Water Policy): Rosenberg International Forum: The Mackenzie River Basin, Report of the Rosenberg International Forum's workshop on transboundary relations in the Mackenzie River Basin, June 2013, 41 pp., 2013.

Robinson, D. A. and Frei, A.: Seasonal variability of northern hemisphere snow extent using visible satellite data, Prof. Geogr., 52, 307-315, 2000.

Robinson, D. A., Dewey, K. F., and Heim, R. R.: Global snow cover monitoring: an update, B. Am. Meteorol. Soc., 74, 1689-1696, 1993.

Rood, S. B., Pan, J., Gill, K. M., Franks, C. G., Samuelson, G. M., and Shepherd, A.: Declining summer flows of Rocky Mountain rivers: Changing seasonal hydrology and probable impacts on floodplain forests, J. Hydrol., 349, 397-410, 2008.

Rood, S. B., Samuelson, G. M., Weber, J. K., and Wywrot, K. A.: Twentieth-century decline in streamflows from the hydrographic apex of North America, J. Hydrol., 306, 215-233, 2005.

Schiefer, E., Menounos, B., and Wheate, R.: Recent volume loss of British Columbian glaciers, Canada, Geophys. Res. Lett., 34, L16503, doi:10.1029/2007GL030780, 2007.

Schuur, E. A. G., McGuire, A. D., Schädel, C., Grosse, G., Harden, J. W., Hayes, D. J., Hugelius, G., Koven, C. D., Kuhry, P., Lawrence, D. M., and Natali, S. M.: Climate change and the permafrost carbon feedback, Nature, 520, 171-179, 2015.

Sellers, P. J., Hall, F. G., Kelly, R. D., Black, A., Baldocchi, D., Berry, J., Ryan, M., Ranson, K. J., Crill, P. M., Lettenmaier, D. P., Margolis, H., Cihlar, J., Newcomer, J., Fitzjarrald, D., Jarvis, P. G., Gower, S. T., Halliwell, D., Williams, D., Goodison, B., Wickland, D., and Guertin, F. E.: BOREAS in 1997: Experiment overview, scientific results, and future directions, J. Geophys. Res.-Atmos., 102, 28731-28769, 1997.

Sen, P. K.: Estimates of the regression coefficient based on Kendall's tau, J. Am. Stat. Assoc., 63, 1379-1389, 1968.

Serreze, M. C., Walsh, J. E., Chapin III, F. S., Osterkamp, T., Dyurgerov, M., Romanovsky, V., Oechel, W. C., Morson, J., Zhang, T., and Barry, R. G.: Observational evidence of recent change in the northern high-latitude environment, Clim. Change, 46, 159-207, 2000.

Shabbar, A. and Bonsal, B.: An assessment of changes in winter cold and warm spells over Canada, Nat. Hazards, 29, 173-188, 2003.

Shabbar, A. and Bonsal, B.: Associations between low frequency variability modes and winter temperature extremes in Canada, Atmos.-Ocean, 42, 127-140, 2004.

Shabbar, A. and Skinner, W.: Summer drought patterns in Canada and the relationship to global sea surface temperatures, J. Climate, 17, 2866-2880, 2004.

Shabbar, A., Bonsal, B., and Khandekar, M.: Canadian precipitation patterns associated with the Southern Oscillation, J. Climate, 10, 3016-3027, 1997.

Shi, X., Marsh, P., and Yang, D.: Warming spring air temperatures, but delayed spring streamflow in an Arctic headwater basin, Environ. Res. Lett., 10, 064003, doi:10.1088/17489326/10/6/064003, 2015.

Shook, K. and Pomeroy, J.: Changes in the hydrological character of rainfall on the Canadian prairies, Hydrol. Process., 26, 17521766, 2012.

Smith, S. L.: Trends in permafrost conditions and ecology in northern Canada, Canadian Biodiversity: Ecosystem Status and Trends 2010, Technical Thematic Report No. 5. Canadian Councils of Resource Ministers. Ottawa, ON, III + 22 pp., 2011.

Smith, S. L., Burgess, M. M., Riseborough, D., and Nixon, F. M.: Recent trends from Canadian permafrost thermal monitoring network sites, Permafrost Periglaciol., 16, 19-30, 2005.

Smith, S. L., Burgess, M. M., and Riseborough, D. W.: Ground temperature and thaw settlement in frozen peatlands along the Norman Wells pipeline corridor, NWT Canada: 22 years of monitoring, in: Proceedings of the Ninth International Conference on Permafrost, Fairbanks, AK, 29 June to 3 July, 2008, edited by: Kane, D. L., and Hinkel, K. M., Institute of Northern Engineering, University of Alaska Fairbanks, Vol. 2, 1665-1670, 2008.

Smith, S. L., Wolfe, S. A., Riseborough, D. W., and Nixon, F. M.: Active-layer characteristics and summer climatic indices, Mackenzie Valley, Northwest Territories, Canada, Permafrost Periglaciol., 20, 201-220, 2009.

Smith, S. L., Romanovsky, V. E., Lewkowicz, A. G., Burn, C. R., Allard, M., Clow, G. D., Yoshikawa, K., and Throop, J.: Thermal state of permafrost in North America: A contribution to the International Polar Year, Permafrost Periglaciol., 21, 117-135, 2010.

Spence, C.: Hydrological processes and streamflow in a lake dominated watercourse, Hydrol. Process., 20, 3665-3681, 2006.

Spence, C. and Rausch, J.: Autumn synoptic conditions and rainfall in the subarctic Canadian Shield of the Northwest Territories, Canada, Int. J. Climatol., 25, 1493-1506, 2005.

Spence, C. and Woo, M. K.:, Hydrology of the northwestern subarctic Canadian Shield, in: Cold Region Atmospheric and Hydrologic Studies, the Mackenzie GEWEX Experience, Volume 2: Hydrologic Processes, edited by: Woo, M. K., Springer, Berlin Heidelberg, 235-256, 2008.

Spence, C., Kokelj, S. V., and Ehsanzadeh, E.: Precipitation trends contribute to streamfow regime shifts in northern Canada, in: Cold Region Hydrology in a Changing Climate, Publ. 346, IAHS, Wallingford, UK, 3-8, 2011. 
Spence, C., Kokelj, S. A., Kokelj, S. V., and Hedstrom N.: The process of winter streamfow generation in a subarctic Precambrian Shield catchment, Hydrol. Process., 28, 4179-4190, 2014.

Spence, C., Kokelj, S. V., Kokelj, S. A., McCluskie, M., and Hedstrom N.: Evidence of a change in water chemistry in Canada's subarctic associated with enhanced winter streamflow, J. Geophys. Res.-Biogeosci., 120, 113-127, 2015.

Squires, M.: Spatial and temporal trends in snow conditions in the NWT: An analysis of snow data collected by AANDC Water Resources Division 1965-2010, Report by Water Matters Environmental Consulting, March 2014, 68 pp., 2014.

St. Jacques, J. M. and Sauchyn, D. J.: Increasing winter baseflow and mean annual streamflow from possible permafrost thawing in the Northwest Territories, Canada, Geophys. Res. Lett., 36, L01401, doi:10.1029/2008GL035822, 2009.

St. Jacques, J. M., Sauchyn, D. J., and Zhao, Y.: Northern Rocky Mountain streamflow records: Global warming, trends, human impacts or natural variability?, Geophys. Res. Lett., 37, L06407, doi:10.1029/2009GL042045, 2010.

Stewart, R. E., Leighton, H. G., Marsh, P., Moore, G. W. K., Ritchie, H., Rouse, W. R., Soulis, E. R., Strong, G. S., Crawford, R. W., and Kochtubajda, B.: The Mackenzie GEWEX Study: The water and energy cycles of a major North American River Basin, B. Am. Meteorol. Soc., 79, 2665-2683, 1998.

Stewart, R., Pomeroy, J., and Lawford, R.: The Drought Research Initiative: A comprehensive examination of drought over the Canadian prairies, Atmos.-Ocean, 49, 298-302, 2011.

Stone, D. A., Waever, A. J., and Zwiers, F. W.: Trends in Canadian precipitation intensity, Atmos.-Ocean, 38, 321-347, 2000.

Tedesco, M., Brodzik, M., Armstrong, R., Savoie, M., and Ramage, J.: Pan arctic terrestrial snowmelt trends (1979-2008) from spaceborne passive microwave data and correlation with the Arctic Oscillation, Geophys. Res. Lett., 36, L21402, doi:10.1029/2009GL039672, 2009.

Tennant, C. and Menounos, B.: Glacier change of the Columbia Icefield, Canadian Rocky Mountains, 1919-2009, J. Glaciol., 59, 671-686, 2013.

Tennant, C., Menounos, B., Wheate, R., and Clague, J. J.: Area change of glaciers in the Canadian Rocky Mountains, 1919 to 2006, The Cryosphere, 6, 1541-1552, doi:10.5194/tc-6-15412012, 2012.

Tong, J., Déry, S. J., Jackson, P. L., and Derksen, C.: Snow distribution from SSM/I and its relationships to the hydroclimatology of the Mackenzie River Basin, Canada, Adv. Water Res., 33, 667677, 2010.

Vincent, L. A. and Mekis, E.: Changes in daily and extreme temperature and precipitation indices for Canada over the twentieth century, Atmos.-Ocean, 44, 177-193, 2006.

Vincent, L. A., Wang, X. L., Milewska, E. J., Wan, H., Yang, F., and Swail, V.: A second generation of homogenized Canadian monthly surface air temperature for climate trend analysis, J. Geophys. Res., 117, D18110, doi:10.1029/2012JD017859, 2012.

Vincent, L. A., Zhang, X., Brown, R., Feng, Y., Mekis, E. J., Milewska, E., Wan, H., and Wang X. L.: Observed trends in Canada's climate and influence of low-frequency variability modes, J. Climate, 28, 4545-4560, 2015.

Walker, A. E. and Silis, A.: Snow-cover variations over the Mackenzie River basin, Canada, derived from SSM/I passive-microwave satellite data, Ann. Glaciol., 34, 8-14, 2002.
Walvoord, M. and Striegl, R.: Increased groundwater to stream discharge from permafrost thawing in the Yukon River basin: Potential impacts on lateral export of carbon and nitrogen, Geophys. Res. Lett., 34, L12402, doi:10.1029/2007GL030216, 2007.

Wang, X. L., Feng, Y., and Vincent, L. A.: Observed changes in one-in-20 year extremes of Canadian surface air temperatures, Atmos.-Ocean, 52, 222-231, 2014.

White, D., Hinzman, L., Alessa, L., Cassano, J., Chambers, M., Falkner, K., Francis, J., Gutowski, W. J., Holland, M., Holmes, R. M., Huntington, H., Kane, D., Kliskey, A., Lee, C., McClelland, J., Peterson, B., Rupp, T. S., Straneo, F., Steele, M., Woodgate, R., Yang, D., Yoshikawa, K., and Zhang, T.: The arctic freshwater system: Changes and impacts, J. Geophys. Res., 112, G04S54, doi:10.1029/2006JG000353, 2007.

Whitfield, P. H., Hall, A. W., and Cannon, A. J.: Changes in the seasonal cycle in the circumpolar Arctic, 1976-95: Temperature and precipitation, Arctic, 57, 80-93, 2004.

Whitfield, P. H., Moore, R. D., Fleming, S. W., and Zawadzki, A.: Pacific decadal oscillation and the hydroclimatology of western Canada - Review and prospects, Can. Water Resour. J., 35, 1-28, 2010.

Whitfield, P. H., Burn, D. H., Hannaford, J., Higgins, H., Hodgkins, G. A., Marsh, T., and Looser, U.: Reference hydrologic networks I. The status and potential future directions of national reference hydrologic networks for detecting trends, Hydrolog. Sci. J., 57, 1562-1579, 2012.

Woo, M. K.: Permafrost Hydrology, Springer, New York, ISBN 978-3-642-23461-3, 563 pp., 2012.

Woo, M. K. and Thorne, R.: Streamflow in the Mackenzie Basin, Canada, Arctic, 56, 328-340, 2003.

Woo, M. K., Thorne, R., and Szeto, K.: Reinterpretation of streamflow trends based on shifts in large-scale atmospheric circulation, Hydrol. Process., 20, 3995-4003, 2006.

Woo, M. K., Rouse, W. R., Stewart, R. E., and Stone, J. M. R.: The Mackenzie GEWEX Study: A contribution to cold region atmospheric and hydrologic sciences, in: Cold Region Atmospheric and Hydrologic Studies, the Mackenzie GEWEX Experience, Volume 1: Atmospheric Dynamics, edited by: Woo, M. K., Springer, Berlin Heidelberg, 1-22, 2008.

Yang, D., Kane, D., Zhang, Z., Legates, D., and Goodison, B.: Bias correction of long-term (1973-2004) daily precipitation data over the northern regions, Geophys. Res. Lett., 32, L19501, doi:10.1029/2005GL024057, 2005.

Zhang, X., Vincent, L. A., Hogg, W. D., and Niitsoo, A.: Temperature and precipitation trends in Canada during the 20th century, Atmos.-Ocean, 38, 395-429, 2000.

Zhang, X., Harvey, K. D., Hogg, W. D., and Yuzyk, T. R.: Trends in Canadian streamflow, Water Resour. Res., 37, 987-998, 2001 a.

Zhang, X., Hogg, W. D., and Mekis, E.: Spatial and temporal characteristics of heavy precipitation events over Canada, J. Climate, 14, 1923-1936, 2001b.

Zhang, X., Brown, R., Vincent, L., Skinner, W., Feng, Y. and Mekis, E.: Canadian climate trends, 1950-2007, Canadian Biodiversity: Ecosystem Status and Trends 2010, Technical Thematic Report No. 5, Canadian Councils of Resource Ministers, Ottawa, Ontario, IV + 21 pp., 2011. 